\section{Pendahuluan}

Sebagai salah satu varian teori (studi) pascastruktural (Loomba, 2003:318--319; Leonard, 2005:2), kajian wacana pascakolonial (postcolonial study) ternyata tidak hanya berkembang secara eksklusif dalam studi (analisis) produkproduk budaya, tetapi juga merambah ke dunia pendidikan. Di Amerika, misalnya, seorang ahli (pendidik) bernama Vanessa Andreotti, mencoba menelaah dan menemukan berbagai konsep dasar teori pascakolonial, dan pada tahap selanjutnya, berbagai konsep dasar yang ditemukannya dielaborasikan ke dalam ranah pendidikan. Dari hasil elaborasi tersebut, yang kemudian dituangkan ke dalam buku Actionable Postcolonial Theory in Education, Andreotti (2011:261-265) menyimpulkan tiga hal penting dalam kaitannya dengan pendidikan (nilai, karakter).

Pertama, teori (studi) pascakolonial dapat digunakan sebagai landasan untuk mengubah kurikulum yang lebih berorientasi pada pemberian keterampilan kepada peserta didik agar lebih mengenali nilai-nilai diri, empati terhadap orang dalam situasi berbeda, mengakui keabsahan sudut pandang lain, mengenali cara seseorang dalam berhubungan dengan dunia, dan mengenali kemungkinan tindakannya di dan untuk masa depan. Kedua, sesuatu yang diperoleh dari studi pascakolonial dapat memberikan kontribusi bagi penyadaran akan nilai, tanggung jawab sosial, kesetaraan gender, rasa memiliki satu dunia, sarana penegakan demokrasi, bahkan sebagai sarana pemberantasan kemiskinan. Ketiga, dengan memanfaatkan hasil studi wacana pascakolonial, pendidikan akan terarah pada pengembangan kepribadian dan penghargaan atas hak asasi manusia, di samping meningkatkan pengertian, toleransi, persahabatan di antara semua bangsa, kelompok ras atau agama, dan memelihara perdamaian seluruh umat manusia di dunia.

Sebagaimana diketahui bahwa Amerika adalah negara adidaya yang dapat dikategorikan sebagai kolonialis terutama di bidang ekonomi (Lo and Gilbert, 1998). Akan tetapi, menyimak simpulan Andreotti di atas, tampak bahwa ternyata negara Paman Sam itu masih sangat memperhatikan pendidikan (pembangunan) karakter bagi bangsanya. Hal itu diperkuat dengan usahanya merintis dan mengembangkan pendidikan karakter sejak awal dekade 1990- an (Arthur, 2003:119--120). Bahkan, usaha itu lebih dintensifkan lagi setelah terjadi Peristiwa 11 September 2001 (tragedi World Trade Center) dengan fokusnya pada pendidikan nilai (Gardner et al, 2005:1) karena itu, walaupun tidak ingin disebut "mengekor" Amerika, tidaklah berlebihan kalau dalam konteks Indonesia, masalah pendidikan karakter bangsa perlu mendapat perhatian dan layak menjadi program yang penting dan utama.

Dengan tidak bermaksud membandingkan apa yang telah dilakukan Andreotti di Amerika, kajian ini hendak membahas bagaimana dan apa yang dapat diperoleh dari studi wacana (sastra) pascakolonial di Indonesia dalam hubungannya dengan pendidikan karakter bangsa. Hal ini penting dilakukan karena--sebagaimana dicatat oleh Pemerintah RI (2010:2)--sampai saat ini di Indonesia masih terjadi kesenjangan sosialekonomi-politik, ketidakadilan hukum, pergaulan bebas, tindakan anarkis, konflik sosial, korupsi, perilaku tidak santun, tidak jujur, hilangnya rasa toleran, gotong royong, dan penghargaan terhadap pluralitas, yang semua itu menandai bahwa masyarakat Indonesia masih mengalami dekarakterisasi. Sementara, bahasan difokuskan pada wacana sastra karena--sesuai dengan kodrat keberadaannya--karya sastra menawarkan sejumlah nilai (mental-spiritual) yang bermakna dan karya sastra yang baik selalu memberi pesan (nilai, moral) kepada para pembaca agar kualitas hidupnya meningkat (Darma, 1995:105; Sayuti, 2003:7--9). Hal demikian berarti bahwa wacana (karya) sastra pascakolonial yang hidup dalam khasanah sastra Indonesia diasumsikan (secara pragmatis) dapat memberikan pesan (sesuatu yang baik) kepada para pembaca (masyarakat) Indonesia.

Berkenaan dengan hal di atas, dengan menggunakan teori pascakolonial kajian ini hendak membahas bagaimana dampak kolonial dan karakteristik wacana (sastra) pascakolonial di Indonesia. Di samping itu, dengan menggunakan teori pragmatik kajian ini juga akan mambahas bagaimana pascakolonialitas yang melekat pada karya-karya sastra Indonesia itu memiliki peran atau fungsi tertentu dalam konteks pragmatis. Perlu diketahui bahwa dalam pengertian yang paling sederhana teori pascakolonial merupakan studi tentang produk budaya-salah satu di antaranya karya sastra--dari masyarakat terjajah dalam menolak hegemoni penjajah (Lo and Gilbert, 1998). Sementara itu, dalam lingkup 
semiotik, teori pragmatik merupakan studi tentang (tindakan) penggunaan tanda (Seung, 1982:76--80). Dalam kaitan ini, studi pascakolonial berpijak pada analisis teks (pemaknaan semantis); sedangkan studi pragmatik berpijak pada analisis konteks (pemaknaan pragmatis).

Sesuai dengan konsep dasar teori yang telah dikemukakan, pendekatan yang digunakan dalam kajian kualitatif ini adalah pendekatan kritis. Pendekatan kritis adalah pendekatan yang bersifat ideologis yang bertolak dari kebutuhan akan kebebasan dan sekaligus pembebasan (Cooper and White, 2012:17--19). Seperti halnya dalam kajian kualitatif lainnya, pendekatan kritis juga dicirikan oleh usaha pencarian makna dan pemahaman, dan lokus makna itu antara lain terdapat dalam teks naratif. Sementara itu, data dikumpulkan dengan teknik studi dokumen (Stake, 2010:88--103), sedangkan interpretasinya dilakukan dengan teknik analisis isi (content analysis). Akan tetapi, analisis isi tidak dilakukan dengan model frekuensi, tetapi dengan intensitas karena tujuannya membuat inferensi, bukan mendeskripsikan isi (Krippendorff, 2004:15--17). Dalam kaitan ini, pembuatan inferensi dilakukan dengan metode transaksi sebagaimana diterapkan dalam teori respon pembaca (reader response) (Rosenblatt dalam Toha-Sarumpaet, 2010:42--44).

\section{Dampak Kolonial dan Karakteristik Wacana Sastra Pascakolonial}

Sebagaimana diketahui bahwa kolonialisme bermula sejak abad ke-16 ketika bangsa Eropa (Inggris, Perancis) menemukan, menaklukkan, dan kemudian menjajah negara-negara asing seperti India, Afrika, dan Amerika (Kozlowski, 2010:2). Akibat dari penjajahan Eropa itu hingga sekarang lebih dari tiga perempat umat manusia yang hidup di dunia mengalami dekarakterisasi (Ashcroft dkk., 2003:xxi). Hal tersebut terjadi karena dalam proses kolonisasinya Eropa menerapkan bentuk dan institusi politik modern sehingga banyak penduduk pribumi binasa, kebudayaan setempat hancur, orang-orang yang sebelumnya bebas menjadi budak, kekayaan alam dirampas, dan sejenisnya (Ryan, 2011:265--266). Dewasa ini, dengan strategi yang lebih canggih, hal serupa terjadi pula di Timur Tengah (Arab, Irak, Palestina) oleh Amerika (Said, 2010:xvii--xviii).

Bukti tentang terjadinya dekarakterisasi umat manusia itu ternyata tidak hanya terlihat di India, Afrika, dan Amerika akibat penjajahan Eropa atau di Timur Tengah akibat penjajahan Amerika, tetapi juga terlihat di Indonesia akibat penjajahan Belanda selama tiga setengah abad (1596--1945). Pada mulanya, Belanda datang ke Indonesia (1596) hanya untuk tujuan dagang demi kepentingan ekonomi negerinya; dan untuk memenuhi tujuan tersebut Belanda mendirikan VOC (Vereenigde Oost-Indische-Compagnie, 1602). Akan tetapi, pada perkembangan selanjutnya, VOC tidak hanya menjalankan fungsi dagang, tetapi juga fungsi politik. Hal demikian terlihat melalui tindakannya membentuk tentara, polisi, pengadilan, penarik pajak, dan pemberi izin (Simbolon, 2006:46--48). Itulah sebabnya, Gubernur Jenderal tidak hanya berperan sebagai pimpinan perusahaan besar, tetapi juga sebagai pimpinan "negeri jajahan" yang menjalankan sistem politiknya sendiri.

Hanya saja, peran ganda tersebut menyebabkan sistem monopoli yang dijalankannya mengalami kemunduran akibat sikap arogansi dan perbuatan amoral para penguasa. Bukan suatu kebetulan, pada saat itu juga terjadi perebutan hegemoni perdagangan dengan Inggris, dan dalam perebutan itu Belanda menderita kerugian besar, sehingga pada tahun 1798 VOC dibubarkan (Kartodirjo, 1975:1). Kendati demikian, pada masa-masa berikutnya Belanda tetap menjalankan fungsi politik dan eksploitasi ekonomi melalui sistem tanam paksa (cultuur stelsel) gagasan Van den Bosch (1830). Namun, karena sistem tanam paksa ternyata juga semakin membuat rakyat menderita, akibatnya muncullah berbagai perlawanan, di antaranya Perang Paderi di Sumatra Barat dan Perang Diponegoro di Jawa (Simbolon, 2006:129--132). Bahkan, perlawanan itu juga datang dari orang Belanda seperti yang dilakukan oleh Multatuli melalui Max Havelaar (1860). Jauh sesudah itu, setelah dijalankannya Politik Etis (1901) sebagai usaha "membayar hutang kehormatan" dengan fokusnya pada program edukasi, irigasi, dan emigrasi, jumlah kaum terdidik pribumi (elite baru) kian bertambah sehingga muncul kesadaran bersama bahwa Indonesia harus menentukan nasib sendiri sebagai bangsa. Itu sebabnya, bangsa Indonesia kemudian berhasil memproklamasikan kemerdekaannya pada 17 Agustus 1945.

Walaupun secara politik Indonesia telah merdeka, dampak kolonialisme Belanda ternyata masih terasa hingga sekarang (Bogaerts, 2011:278--281). Pada mulanya, bangsa Indonesia, termasuk bangsa-bangsa lain yang pernah mengalami kolonisasi (India, Afrika, Philipina, dII), 


\section{Dinyatakan dengan tegas bahwa} sumber kemiskinan dan penderitaan rakyat bukanlah feodalisme, melainkan imperialisme dan kolonialisme Belanda.

tidak menyadari betapa efek kolonialisme masih demikian kuat. Akan tetapi, setelah kajian budaya (cultural studies) khususnya studi pascakolonial muncul sejak dekade 1990-an--hal ini sebenarnya telah dirintis oleh Frans Fanon pada tahun 1960an--, kesadaran tentang dampak buruk kolonial semakin nyata dirasakan. Lebih-lebih, setelah para ahli (Edward Said, Gayatri Spivak, Homi K. Bhabha, Bill Aschcroft dkk, Tineke Hellwig, Keith Foulcher, Pamela Allen, Evan Winet, Faruk, dII) banyak melakukan kajian kritis terhadap dampak kolonial di Timur Tengah, India, Afrika, dan Indonesia, semakin disadari bahwa kita (bangsa Indonesia) sebenarnya masih berada dalam bayang-bayang kolonialisme.

Memang, benar bahwa kalau kita membaca pikiran, sikap, dan perilaku yang direpresentasikan dalam berbagai karya sastra Indonesia, praktik kekuasaan kolonial Belanda tampak menjadi wahana ekspresi yang penting bagi sastrawan Indonesia. Semaoen dalam novelnya Hikayat Kadiroen (1920), misalnya, merepresentasikan betapa rakyat pribumi menderita dan miskin akibat penjajahan. Dinyatakan dengan tegas bahwa sumber kemiskinan dan penderitaan rakyat bukanlah feodalisme, melainkan imperislisme dan kolonialisme Belanda. Dalam konteks ini, Semaoen menolak pandangan Max Havelaar yang menyatakan bahwa kemiskinan rakyat hanya dapat diatasi dengan intervensi pemerintah Belanda. Bagi Semaoen tidaklah demikian karena penderitaan rakyat hanya dapat diatasi dengan cara menggalang kekuatan (kemerdekaan) rakyat itu sendiri (Faruk, 2007:307).

Sementara itu, Marah Rusli, dalam novelnya Sitti Nurbaya (1922), menyuarakan suara pegawai pribumi dalam sistem birokrasi kolonial Belanda dalam berhadapan dengan pemerintah dan dengan rakyat setempat (Minangkabau) (Faruk, 2007:360). Di balik suara itu novel Sitti Nurbaya memperlihatkan adanya dualisme dalam sistem politik, ekonomi, sosial, dan budaya di Indonesia. Di satu pihak masyarakat setempat (pribumi) hidup dalam dan dengan sistem politik, ekonomi, sosial, dan budaya tradisional, tetapi di lain pihak mereka juga hidup dalam tatanan kolonial yang berlaku dalam semua sektor kehidupan. Dalam dualisme tersebut sistem yang satu tidak terpisah dari yang lain, tetapi cenderung saling melintasi, bahkan tumpang tindih sehingga menimbulkan pengalaman dan respon yang khas pada masyarakat Indonesia. Selain itu, melalui novel tersebut dapat dilihat bahwa dalam batas tertentu penjajahan Belanda di Indonesia memiliki kekuatan pengaruh yang sama dengan penjajahan bangsa Eropa lainnya di seluruh dunia; dan pejajahan itu tidak hanya bersifat dominasi politik, tetapi juga kultural-hegemonik.

Dalam novel Salah Asuhan (1928) Abdoel Moeis juga mengungkap praktik kekuasaan kolonial dan dampaknya bagi pribumi. Kalau dicermati, yang penting dalam novel ini sebenarnya bukan lagi masalah kawin paksa, melainkan efek yang ditimbulkan oleh perjumpaan dua budaya yang berbeda (kolonial dan pribumi). Oleh karena itu, tokoh utama (Hanafi) dalam novel ini mengalami alienasi, terasing, dan terombang-ambing. Di satu sisi, Hanafi ingin menjadi Belanda dengan segala daya upaya melakukan peniruan (mimikri) terhadap bahasa, gaya hidup, dan perilaku keBelanda-annya. Akan tetapi, di kalangan Belanda ia tetap saja dianggap pribumi, dianggap "orang lain" (the other), dan tidak diterima sebagai Belanda. Sementara itu, di sisi lain, Hanafi terlanjur meninggalkan adat-istiadat kepribumiannya sehingga ia pun "ditolak" ketika ingin kembali ke asalnya. Itulah sebabnya, Hanafi kehilangan identitas akibat begitu kuatnya relasi kuasa kolonial yang hierarkis.

Halnya berbeda jika kita membaca novel Bumi Manusia (1980) karya Pramoedya Ananta Toer. Kalau di dalam Sitti Nurbaya dan Salah Asuhan sikap perlawanan (resistensi) terhadap praktik kekuasaan kolonial Belanda hanya tampak samar, dalam novel produksi "Pulau Buru" ini sikap demikian terlihat jelas. Sikap demikian tampak pada proses terjadinya resistensi, sedangkan proses terjadinya resistensi dapat dilihat pada figur tokoh resistensi (mimic man, colonial subject). Figur tokoh resistensinya adalah Minke karena ia adalah pribumi yang mengakui otoritas ilmu pengetahuan Barat dan pribumi yang berpendidikan Barat. Akan tetapi, Minke sekaligus mengacaukannya karena selain menimba ilmu pengetahuan Barat ia juga belajar Babad Tanah Jawa (Noor, 2002:177). Oleh karena itu, tindakan mimikri yang dilakukan menyadarkan dirinya akan adanya penindasan sehingga kesadaran tersebut 
digunakan untuk melawan praktik kekuasaan kolonial yang sewenang-wenang.

Perlawanan terhadap praktik kekuasaan kolonial yang menindas juga secara bagus direpresentasikan dalam Burung-Burung Manyar (1981) karya Mangunwijaya. Novel ini tidak hanya memperjuangkan pribumi dalam cengkeraman atau bayang-bayang kekuasaan Belanda, tetapi juga berusaha membongkar praktik kekuasaan yang dijalankan pemerintah (Orba), bahkan juga sekaligus menantang praktik budaya priyayi. Oleh karena itu, dari sudut pandang pascakolonial, melalui proses hibridisasi tokohnya (Teto), novel ini tidak sekadar melawan kolonialisme dan imperialisme, tetapi juga melawan feodalisme. Hanya saja, tokoh utama novel ini kemudian kehilangan tempat, kehilangan identitas, karena di samping sebagai tentara KNIL yang sering mendapat julukan sinyo (Belanda), ia sesungguhnya juga seorang priyayi. Oleh karenanya, sebagai satir politik Burung-Burung Manyar tidak sekadar bersikap resisten terhadap kolonialisme, tetapi, yang lebih utama, adalah mendekonstruksi narasi besar revolusi atau ingin membongkar sejarah nasional (Allen, 2004:208209). Hal serupa tampak juga dalam Durga Umayi (1991), novel Mangunwijaya yang lain. Novel ini tidak lagi melihat persoalan kolonial sebagai hal yang penting, tetapi yang lebih penting adalah mengedepankan persoalan kematian rasionalitas. Hal tersebut berarti bahwa makna pascakolonial harus dipahami sebagai proses menolak kolonisasi tanpa perlu menolak orang Belanda (Allen, 2004:254).

Bukti menunjukkan bahwa konstruksi (praktik) kekuasaan kolonial ternyata masih menjadi wahana ekspresi sastra tahun 2000-an. Sebagai contoh, misalnya, beberapa novel karya Suparto Brata. Dalam Saksi Mata (2002), misalnya, Suparto Brata menggambarkan dampak kekuasaan kolonial Jepang di Indonesia menjelang kemerdekaan. Bagaimana perlakuan semena-mena Tuan Ichiro terhadap Bulik Rum dan keluarga-(keraton)-nya digambarkan secara detail dan intens dalam novel ini. Sementara, dalam triloginya, yakni Gadis Tangsi (2004), Kerajaan Raminem (2006), dan Mahligai di Ufuk Timur (2007). Suparto Brata juga mengekspresikan beragam karakter kehidupan di bawah bayang-bayang kekuasaan kolonial pada masa akhir pemerintahan Belanda, Jepang, dan awal kemerdekaan. Dalam trilogi ini tokoh Teyiwalaupun tidak pernah sekolah--berusaha keras dengan cara belajar (meniru, mimikri) bahasa
Belanda dan Jawa halus (keraton) agar identitas dan dirinya diterima (diakui) oleh Belanda dan Tionghoa. Hanya saja, peniruan yang dilakukan tidak dimaksudkan sebagai bentuk perlawanan (resistensi) terhadap kolonialisme, tetapi lebih sebagai perlawanan terhadap kebodohan diri (dan masyarakat pribumi). Walau dalam kadar yang berbeda, hal serupa terlihat juga dalam Mencari Sarang Angin (2005), Republik Jungkir Balik (2009), dan Tak Ada Nasi Lain (2013).

Selain direpresentasikan dalam karya-karya fiksi (novel), praktik kekuasaan kolonial yang hierarkis juga direpresentasikan dalam karyakarya drama (teater) Indonesia. Hal demikian, misalnya, dapat dibaca pada hasil penelitian Winet (2010). Dalam penelitiannya Winet mengkaji pascakolonialitas teater Indonesia, terutama teater yang berkembang di Jakarta sejak awal hingga melintasi tiga generasi (Sukarno, Suharto, Reformasi). Pada awalnya Winet mengulas sejarah teater kolonial untuk melacak kemungkinan adanya kanonisasi. Kemudian ia membandingkannya dengan beberapa teater etnik, di antaranya teater Cina (Tionghoa). Dari upaya pembandingan itu Winet kemudian membahas beberapa teater yang menyuarakan revolusi kemerdekaan, lalu dilanjutkan dengan kajian beberapa teater yang memfokuskan perhatian pada berbagai kritik atas situasi politik yang mendominasi rezim tertentu. Teater pada masa Suharto, misalnya, dipenuhi nuansa kritik atas rezim Sukarno, demikian juga teater pada masa Reformasi sarat dengan kritik atas rezim Suharto. Dari kajian itu akhirnya Winet berkesimpulan bahwa dalam sepanjang sejarahnya wacana teater Indonesia selalu dibayangi oleh praktik-praktik kekuasaan kolonial, baik kekuasaan kolonial Belanda maupun kekuasaan kolonial model baru (negara atas rakyatnya) atau neokolonialisme.

Demikian gambaran singkat mengenai praktik-praktik (konstruksi) kekuasaan kolonial yang direpresentasikan dalam beberapa karya sastra Indonesia. Gambaran tersebut tidak dimaksudkan sebagai gambaran yang mewakili seluruh pembicaraan mengenai pascakolonialitas sastra Indonesia. Sesungguhnya masih banyak karya lain yang mengangkat persoalan tersebut, tetapi sebagai sebuah ilustrasi, apa yang telah digambarkan di atas dirasa cukup. Secara garis besar, dari gambaran itu dapat dicatat beberapa ciri (karakteristik) penting yang melekat pada wacana (karya sastra) pascakolonial. Ciri-ciri tersebut ialah (1) adanya relasi kuasa yang hierarkis-dominatif 
(superior, inferior, subaltern), (2) munculnya identitas ganda (diaspora, hibridisasi), (3) adanya usaha peniruan (mimikri, kreolisasi, ambivalensi, moccery), dan (4) munculnya aspek perlawanan (resistensi, ironi, kompromi, dekonstruksi). Ciri atau karakteristik (pascakolonialitas) demikian yang pada umumnya menjadi perhatian utama bagi para ahli ketika melakukan kajian wacana (karya sastra) pascakolonial. Selanjutnya penjelasan mengenai beberapa karakteristik tersebut sebagai berikut.

\section{1) Relasi Kuasa}

Sejarah mencatat bahwa kolonialisme terbangun oleh relasi kuasa yang tidak seimbang. Dari bangunan relasi kuasa itu, muncullah beragam dikotomi tentang identitas budaya: penjajah-terjajah, superior-inferior, penguasayang dikuasai, pusat-pinggiran, kita-mereka (orang lain), baik-buruk, beradab-biadab, bersuara-diam, dan sejenisnya. Hal ini terbukti melalui arogansi Belanda ketika meng klasifikasikan masyarakat Hindia menjadi tiga golongan, yaitu golongan Eropa (Belanda), golongan Timur Asing (Cina dan Arab), dan golongan Pribumi (Kartodirjo, 1975:155--156). Dalam klasifikasi ini Eropa menempatkan diri pada posisi superior, sementara Pribumi ditempatkan pada posisi inferior sehingga Eropa (Belanda) menjadi subjek yang dapat memperlakukan apa pun terhadap objeknya (pribumi). Oleh karena itu, kaum pribumi akhirnya berada dalam keadaan terpinggirkan (subaltern) akibat kuatnya dominasi kekuasaan. Keterpinggiran pribumi itu pada akhirnya berubah menjadi sebuah keniscayaan (hegemonik) karena dalam usaha mempertahankan kekuasaannya penjajah terusmenerus memproduksi dan mereproduksi wacana tentang "kehebatan" penjajah (Eropa/Barat). Sementara, dalam relasi ini, pribumi terpaksa (dipaksa) harus mengakuinya (legitimatif).

\section{2) Identitas Ganda}

Pada dasarnya penjajahan adalah penguasaan bangsa (penjajah) atas bangsa lain (terjajah). Penguasaan itu tidak berarti hanya sekadar pengambilalihan wilayah (tempat, tanah), tetapi juga identik dengan pemaksaan, baik pemaksaan pola pikir, sikap, perilaku, bahasa, dan sejenisnya sehingga terjadilah interaksi silang budaya (hibridisasi). Oleh sebab itu, problem yang kemudian dihadapi oleh pribumi (terjajah) adalah problem identitas karena baginya identitas tidak ditentukan oleh diri sendiri, tetapi dikonstruksi oleh yang berkuasa (penjajah) (Bhabha, 1994:44). Di satu sisi, seseorang (terjajah) mungkin berkehendak untuk mengikuti pola pikir, sikap, dan perilaku penjajah, tetapi di sisi lain ia terikat oleh pola pikir, sikap, dan perilaku budaya pribuminya. Atau, yang seringkali terjadi, kehendak untuk masuk ke dalam budaya penjajah (hibridisasi) tetap saja tidak memperoleh pengakuan, padahal ia sudah terlanjur berperilaku seperti penjajah yang semena-mena terhadap kaumnya (terjajah) sendiri. Itulah sebabnya, sebagai seorang diaspora ia akhirnya kehilangan identitas (terasing, teralienasikan, atau ber-identitas ganda).

\section{3) Usaha Peniruan (Mimikri)}

Akibat dari adanya interaksi silang budaya (penjajah dan terjajah), atau karena secara hegemonik penjajah berhasil meyakinkan bahwa penjajah (Barat, Eropa) adalah superior yang akan mampu menaikkan derajat terjajah, kaum terjajah (pribumi) kemudian berkeinginan untuk menyamai penjajah. Pada umumnya upaya yang dilakukan adalah dengan cara peniruan (mimicry), emansipasi, misalnya peniruan terhadap gaya hidup, bahasa (kreolisasi), dan sejenisnya agar memperoleh derajat (martabat) yang sama dengan penjajah (Bhabha, 1994:85--92). Akan tetapi, karena kaum pribumi masih berada dalam serba keterbatasan, upaya emansipasi dan peningkatan martabat itu tetap menjadi problem tersendiri karena emansipasi dan peniruan selalu bersifat ambigu (ambivalensi) bahkan berubah menjadi ejekan atau olok-olok (moccery) (Faruk, 2001:74--75). Artinya, di satu pihak pribumi berusaha membangun persamaan, tetapi di lain pihak pribumi juga mempertahankan perbedaan.

\section{4) Perlawanan (Resistensi)}

Walaupun menduduki posisi inferior, yang identitasnya ditentukan oleh penguasa dan keberadaannya ditindas oleh penjajah, tidak berarti bahwa kaum pribumi tidak berkeinginan untuk bangkit dan melawan penjajahan (penindasan). Hanya saja, perlawanan (resistensi) yang dilakukan umumnya banyak menghadapi kendala dan tidak mencapai hasil yang diharapkan sehingga ia cenderung mendua yang terkadang berubah hanya menjadi sebuah ironi. Sementara 
itu, tidak jarang apa yang dilakukannya justru berkompromi dengan aparatus yang dilawannya. Hanya saja, dalam konteks perkembangan studi wacana pascakolonial belakangan ini, resistensi tidak hanya diartikan sebagai usaha melakukan perlawanan terhadap kolonialisme dan imperialisme dalam pengertian yang sempit (penjajahan bangsa atas bangsa lain), tetapi juga dipahami sebagai usaha membongkar (mendekonstruksi) pikiran, sikap, dan perilaku diri (pribumi) yang menyebabkan keterbelakangan, kemiskinan, dan atau kebodohan.

\section{Pascakolonialitas Sastra Indonesia dalam Konteks Pragmatis}

Dalam bahasan sebelumnya telah dipaparkan pascakolonialitas atau ciri-ciri (karakteristik) umum yang melekat pada wacana (karya) sastra Indonesia. Dilihat dari sudut pandang pragmatik-yang menjadi varian penting dalam studi semiotik--, pascakolonialitas yang direpresentasikan dan melekat dalam teks itu menjadi tanda (sign) baru --akibat dari proses pembacaan pascakolonial-yang berfungsi sebagai kode khas yang dikirim pengarang melalui saluran (teks) dan yang memungkinkan terjadinya komunikasi estetis (Segers, 2000:15--21) antara teks dan pembaca. $\mathrm{Hal}$ itu berarti bahwa dalam konsep pragmatik, pascakolonitalitas menjadi kode tertentu--yang oleh Eco (1976:141) disebut pesan yang sudah dikodekan (coded massages) atau teks yang sudah dapat dibaca (coded text)--yang secara indeksikal memicu munculnya serangkaian tindakan para pengguna kode tersebut. Dalam konteks ini, salah satu di antara para pengguna itu ialah pembaca.

Sebagai penikmat sastra Indonesia, para pembaca tentu dapat menggunakan apa yang telah diniatkan, diekpresikan, dan direpresentasikan oleh pengarang dalam karya-karya sastra Indonesia. Hal demikian sesuai dengan pengertian bahwa sebagai fakta kemanusiaan karya sastra dicipta oleh pengarang dan tindakan penciptaan itu dilakukan dengan tujuan tertentu, yang salah

... kualitas teks sastra tidak

hanya terletak pada elemen

konstitutifnya, tetapi juga pada

bagaimana para pembaca

memberikan tekanan nilai

kepadanya satunya adalah agar nilai-nilainya (ideologinya) dinikmati (digunakan untuk tujuan tertentu) oleh pembaca. Dalam konteks kajian ini, karena kode khas yang disampaikan dalam wacana (karya) sastra pascakolonial adalah pascakolonialitas (relasi kuasa, identitas, mimikri, dan resistensi), pertanyaan yang muncul adalah digunakan untuk (mencapai tujuan) apakah pascakolonialitas itu? Hasil pengamatan menunjukkan bahwa karakteristik (ciri) wacana sastra pascakolonial sebagaimana telah dipaparkan setidaknya dapat digunakan untuk dua tujuan, yaitu (1) pascakolonialitas sebagai referensi gagasan tematis dan (2) gagasan tematis sebagai media proyeksi pragmatis.

\section{1) Pascakolonialitas sebagai Referensi Gagasan Tematis}

Fakta menunjukkan bahwa kualitas teks sastra tidak hanya terletak pada elemen konstitutifnya, tetapi juga pada bagaimana para pembaca memberikan tekanan nilai kepadanya (Segers, 2000:22). Serangkaian tekanan nilai yang diberikan oleh pembaca itulah yang kemudian terartikulasikan ke dalam berbagai bangunan gagasan tematis tertentu. Oleh sebab itu, dalam konteks kajian ini, asumsi yang dapat diajukan ialah bahwa serangkaian nilai yang terelaborasi dalam berbagai aspek pascakolonial tersebut (relasi kuasa, identitas, mimikri, dan resistensi) akan dapat membangun gagasan-gagasan (ideologi) tematis sebagai berikut.

(a) Relasi kuasa akan membangun gagasan demokratis, cinta damai, dan peduli sosial. Seperti diketahui bahwa relasi kuasa adalah hubungan tidak seimbang antara penguasa (penjajah) dan yang dikuasai (rakyat, terjajah). Ketidakseimbangan itu terjadi karena penguasa terus-menerus melakukan tindakan dengan cara tertentu agar kekuasaannya langgeng (bertahan). Dengan kekuasaannya penguasa mengatur, menekan, mengeksploitasi, dan sejenisnya sehingga rakyat (yang dikuasai) dalam posisi lemah tidak kuasa melakukan tindakan penolakan. Jelas bahwa pola relasi semacam ini jauh dari sifat demokratis, cinta damai, dan peduli sosial. Sebab, pihak satu (penguasa) tidak menghargai dan tidak peduli pada pihak lain (rakyat) sehingga tidak mungkin terbangun suatu perdamaian. Akan tetapi, mengapa pola hubungan (relasi) semacam ini, baik sengaja maupun tidak, direpresentasikan oleh pengarang dalam karya sastra ciptaannya? 
Pembaca dapat menduga bahwa sebenarnya ekspresi dan representasi realitas imajiner demikian tidak dimaksudkan sebagai sebuah contoh, tetapi sebagai cermin realitas empirik yang bermakna sebaliknya. Bahwa pengarang mengekspresikan fakta imajiner tentang akibat buruk dari pola relasi semacam itu dapat dipahami sebagai sebuah ajakan agar pembaca (kita) tidak mengikuti, apalagi menciptakan, pola yang demikian. Sebab, pola hubungan demikian hanya akan melahirkan ketertindasan, ketercerai-beraian, dan ketidakpedulian. Betapa sengsara Bulik Rum, keluarga, dan suaminya akibat perlakuan penguasa Jepang (Tuan Ichiro) dalam novel Saksi Mata, betapa menderita perjalanan orang-orang tangsi akibat perlakuan tentara Jepang ketika terjadi agresi militer ke Indonesia dalam trilogi novel Gadis Tangsi, dan betapa sakit Minke dilecehkan oleh Robert Suurhof dan Nyai Ontosoroh diperkosa oleh Tuan Herman Mellema dalam novel Bumi Manusia, adalah beberapa contoh gambaran mengenai bagaimana akibat buruk dari pola relasi yang dominatif dan menindas itu.

(b) Identitas ganda akan membangun sikap toleran, menghargai (prestasi) orang lain, dan tanggung jawab. Seperti diketahui bahwa identitas ganda terjadi akibat adanya persilangan budaya yang berbeda. Pikiran, perasaan, dan perilaku budaya tertentu akan berpengaruh pada pikiran, perasaan, dan perilaku budaya yang lain. Tentu saja, tidak terelakkan, pikiran, perasaan, dan perilaku budaya dominan (Barat, Eropa, penjajah) akan lebih kuat pengaruhnya pada pikiran, perasaan, dan perilaku budaya kelompok lemah (Timur, terjajah). Dalam hal saling pengaruh yang tidak seimbang ini, yang lebih rentan terhadap perubahan adalah kelompok lemah. Oleh sebab itu, kelompok lemah (terjajah) kemudian tercerabut dari akar budayanya dan terbawa arus ke dalam perilaku budaya dominan. Akan tetapi, usaha kelompok lemah masuk ke dalam perilaku budaya dominan tetap tidak berhasil karena ego budaya dominan begitu kuat. Itulah sebabnya, kelompok lemah, yang dalam wacana pascakolonial biasanya diperankan oleh tokoh sebagai agen perubahan, berada dalam situasi yang mengambang. Dalam situasi demikian si agen kemudian terjebak ke dalam posisi yang ditolak oleh keduanya sehingga muncullah sikap-sikap yang jauh dari toleransi, penghargaan, dan tanggung jawab. Kendati demikian, pertanyaan yang dapat diajukan kemudian ialah, mengapa hal itu diekspresikan para pengarang dalam karya ciptaannya?

Dalam konteks demikian pembaca dapat pula memahami apa sebenarnya yang dimaksud dalam gambaran semacam itu. Bahwa persilangan budaya, saling pengaruh pikiran, perasaan, dan perilaku antarbudaya adalah suatu keniscayaan, sehingga hal itu harus dipahami sebagai suatu kewajaran. Kalau demikian halnya, berarti bahwa identitas tertentu (yang berbeda) harus dihargai dalam kerangka multikulturalisme, sehingga siapa pun diharapkan dapat memberi ruang (toleransi) untuk keberadaannya bagi keragaman identitas tersebut. Sebab, bagaimana pun juga, setiap manusia (masyarakat, bangsa), walaupun identitasnya berbeda-beda, dalam setiap tindakannya akan selalu dituntut (memiliki) prestasi dan tanggung jawabnya. Oleh sebab itu, tidak pada tempatnya kalau Hanafi dipandang memiliki kepribadian aneh di mata bumiputra dan di mata Belanda hanya karena menikahi Corry (gadis Belanda) dalam novel Salah Asuhan, dan tidak pada tempatnya pula kalau Teto dianggap berkepribadian asing hanya karena sebagai priyayi ia menjadi tentara KNIL dan membela Belanda dalam novel Burung-Burung Manyar. Sebab, sesungguhnya, mereka (yang berkepribadian ganda) adalah agen-agen perubahan yang memang harus ada --walaupun menjadi korban-- demi tujuan tertentu (yang lebih besar).

(c) Mimikri akan membangun tindakan rasa ingin tahu, kerja keras, kreatif, disiplin, dan mandiri. Dalam konteks wacana pascakolonial, mimikri adalah tindakan peniruan, usaha emansipasi, yang biasanya diperankan oleh agen (tokoh utama) pribumi dalam rangka meraih derajat, kehormatan, atau status yang sama dengan penjajah. Jelas bahwa usaha peniruan tidak akan dapat dilakukan jika tidak ada rasa ingin tahu lebih besar. Peniruan juga tidak akan berhasil jika tidak ada kerja keras, kreativitas, dan disiplin yang tinggi yang semua itu pada gilirannya akan membangun sikap kemandirian. Memang benar bahwa kalau tidak dilakukan dengan prinsip pengamatan yang selektif dan kreatif, usaha peniruan hanya akan terjebak pada imitasi dan plagiasi. Oleh sebab itu, peniruan (mimikri) dalam konteks ini hendaknya tidak dipahami hanya sebagai peniruan belaka, tetapi juga sebagai langkah yang penuh dedikasi dan kreativitas.

Sehubungan dengan hal di atas, wajarlah kalau dalam usahanya agar diterima di kalangan 
keraton (Surakarta) dan diterima pula di kalangan Belanda tokoh Teyi dalam Gadis Tangsi berusaha keras untuk segera menguasai bahasa Jawa krama, bahasa Belanda, dan adat istiadat budaya Jawa. Sebab, ia berpikir bahwa hanya dengan cara-cara meniru kebiasaan seperti yang dilakukan oleh Belanda, yakni jika ingin maju orang harus banyak membaca, dirinya akan dapat masuk ke dalam lingkungan mereka. Demikian juga Hanafi berusaha meniru gaya hidup Belanda dalam novel Salah Asuhan, atau Minke dan Nyai Ontosoroh berusaha menguasai bahasa Belanda dalam novel Bumi Manusia, semua itu merupakan suatu keniscayaan karena menurut mereka bahasa adalah pintu masuk bagi ilmu pengetahuan (Barat). Karena itu, dalam konteks ini, di balik usaha peniruan muncul sikap atau tindakan kerja keras, kreatif, dan disiplin yang tinggi.

(d) Resistensi akan membangun semangat kebangsaan dan cinta tanah air. Resistensi adalah tindakan perlawanan. Dalam konteks wacana pascakolonial, pada mulanya pengertian resistensi hanya merujuk pada perlawanan terhadap kekuasaan penjajah (kolonial) sehingga apa pun yang berkaitan dengan penjajah harus dilawan. Akan tetapi, dalam perkembangannya kemudian, resistensi dapat dipahami sebagai suatu perlawanan dalam arti luas. Dalam hal ini yang dilawan bukanlah penjajah atau kolonialisnya, melainkan penjajahan atau kolonialisasinya. Oleh karena itu, dalam konteks masa kini, segala bentuk penjajahan harus ditolak, harus dilawan, tetapi perlawanan itu bukan ditujukan kepada bangsa bekas penjajah, melainkan kepada segala jenis/bentuk penjajahan. Sebab, penjajahan dapat saja dilakukan oleh sesama (kelompok, masyarakat, atau bangsa sendiri).

Berkenaan dengan hal tersebut, dalam konteks bahwa resistensi dapat membangun semangat kebangsaan dan cinta tanah air hendaknya dipahami sebagai usaha keras untuk koreksi diri. Kalau memang bangsa ini (Indonesia) menghendaki tidak terjadi penjajahan, baik penjajahan oleh penguasa (pemerintah) pada rakyatnya maupun oleh pihak asing, bentuk resistensi yang mesti dilakukan adalah resistensi yang bersifat membangun. Hal ini misalnya dilakukan dengan cara bersikap positif terhadap visi kebangsaan (keindonesiaan) seperti mencintai produk dan hasil karya bangsa sendiri, lebih mengutamakan bahasa dan budaya sendiri, dan selalu membela tanah air jika terjadi rongrongan dari pihak mana pun. Bahkan tidak hanya itu, yang tidak kalah penting adalah melakukan perlawanan terhadap kemiskinan, tindak kejahatan, dan kebodohan. Semua ini tentu harus dilakukan dengan belajar lebih keras karena hanya dengan cara itulah tujuan kesejahteraan umat manusia tercapai. Oleh sebab itu, bagaimana tokoh Teyi belajar dan bekerja keras hanya untuk meraih sebuah "kehormatan" atau bagaimana Kus Bandarkum berusaha keras masuk tentara PETA dalam novel Gadis Tangsi, atau bagaimana tindakan Darwan lari dari keraton (Surakarta) dan memilih hidup sederhana (menjadi wartawan Dagblad Expres) di Surabaya dalam novel Mencari Sarang Angin, sebenarnya tidak lain adalah demi kemajuan pribumi bangsa ini dan demi cintanya pada tanah air sendiri (Indonesia).

\section{2) Gagasan Tematis sebagai Media Proyeksi Pragmatis}

Fungsi estetis karya seni (sastra) pada dasarnya bersifat dominan dan dinamis, dan akibat dari sifatnya yang demikian fungsi estetis menunjukkan subordinasi fungsi-fungsi lain, di antaranya fungsi praktis. Atau, fungsi estetis pada hakikatnya memiliki beberapa kualitas penting, salah satu di antaranya adalah untuk membangkitkan tindakan (objek) tertentu (Mukarovsky dalam Segers, 2000:32). Itulah sebabnya, asumsi yang dapat diajukan ialah bahwa gagasan-gagasan tematis (ideologi) seperti yang telah dipaparkan di atas akan memiliki makna relasional atau instrumental; dan makna itulah yang dapat digunakan --oleh pembaca dalam rangka realisasi fungsi estetisnya-- sebagai media proyeksi dalam upaya pembinaan atau pembangunan karakter (manusia, masyarakat, bangsa).

Sebagaimana telah dipaparkan, beberapa aspek pascakolonialitas (relasi kuasa, identitas, mimikri, dan resistensi) dalam wacana pascakolonial sastra Indonesia telah melahirkan (menjadi referensi bagi) gagasan-gagasan (ideologi) tertentu, yakni demokratis, cinta damai, peduli sosial, toleran, menghargai (prestasi) orang lain, tanggung jawab, rasa ingin tahu, kerja keras, kreatif, disiplin, mandiri, semangat kebangsaan, dan cinta tanah air. Sebenarnya, kalau dicermati secara lebih dalam lagi, gagasan (ideologi) yang muncul dari pascakolonialitas sastra Indonesia 
tidak hanya terbatas pada itu (13 kata kunci), tetapi lebih banyak lagi sesuai dengan jenisjenis "karakter" (18 kata kunci) seperti yang telah dirumuskan oleh Pemerintah RI (2010:22). Sejumlah gagasan inilah yang oleh pembaca dapat digunakan sebagai proyeksi bagi dirinya untuk merancang (kehidupan) masa depan. Sebab, hanya melalui gagasan semacam itu seseorang akan mampu mengolah hati, mengolah pikir, mengolah raga (kinestetika), dan mengolah rasa dan karsa.

Pada akhirnya, hanya orang yang mampu mengolah hati yang akan dapat bertindak takwa, jujur, amanah, tertib, adil, taat aturan, tanggung jawab, empati pada orang lain, berani mengambil risiko, pantang menyerah, rela berkorban, dan berjiwa patriotik. Hanya orang yang mampu mengolah pikir pula yang akan bisa memiliki sikap cerdas, kritis, kreatif, ingin tahu, inovatif, dan reflektif. Sementara itu, hanya orang yang mampu mengolah raga (kinestetika) saja yang akan selalu bersih, sehat, sportif, tangguh, andal, berdaya tahan, bersahabat, kooperatif, diterminatif, kompetitif, ceria, dan gigih. Selain itu, hanya orang yang mampu mengolah rasa dan karsa yang akan memiliki rasa kemanusiaan, saling menghargai, gotong royong, kebersamaan, ramah, hormat, toleran, nasionalis, peduli, mendunia, mementingkan kepentingan umum, cinta tanah air, bangga berbahasa (dan menggunakan produk) sendiri, dinamis, kerja keras, dan memiliki etos kerja yang tinggi. Sejumlah karakter demikianlah yang, antara lain, terproyeksikan dari karyakarya sastra Indonesia, termasuk di dalamnya karya-karya sastra pascakolonial. Oleh sebab itu, karya-karya sastra semacam ini layak dibaca dan dijadikan bahan pembelajaran di berbagai lembaga pendidikan.

\section{Simpulan}

Dari seluruh pembahasan sebagaimana telah dikemukakan, akhirnya dapat dirumuskan beberapa simpulan berikut. Pertama, sebagai negara yang pernah mengalami kolonialisme, terutama kolonialisme Belanda, terbukti bahwa dampak kolonialisme Belanda masih dirasakan oleh masyarakat Indonesia hingga sekarang. Hal itu terlihat pada berbagai tindakan yang menunjukkan adanya bentuk-bentuk perilaku yang tidak berkarakter (dekarakterisasi). Selain terlihat langsung dalam kehidupan sehari-hari (secara empirik), perilaku tidak berkarakter akibat dari pengalaman kolonialisme itu juga terlihat dalam (dan direpresentasikan oleh pengarang pada) wacana (karya-karya) sastra Indonesia, baik yang terbit pada masa kolonial maupun setelah Indonesia merdeka, bahkan juga masih terlihat pada karya tahun 2000-an.

Kedua, dilihat dari sudut pandang kritik wacana pascakolonial, secara umum karya-karya (teks) sastra pascakolonial di Indonesia memiliki ciri (1) adanya relasi kuasa yang menindas, (2) munculnya identitas ganda, (3) adanya usaha peniruan atau mimikri, dan (4) timbulnya perlawanan atau resistensi. Relasi kuasa terjadi antara penguasa (penjajah, Belanda) dan yang dikuasai (terjajah, pribumi); identitas ganda terjadi akibat adanya persilangan budaya (Barat dan Timur); usaha peniruan terjadi karena si terjajah berkeinginan memperoleh derajat yang sama dengan penjajah; dan resistensi terjadi karena adanya keinginan pribumi untuk melepaskan diri dari penjajahan. Beberapa ciri atau karakteristik (pascakolonialitas) inilah yang secara umum menjadi fokus kajian sastra pascakolonial.

Ketiga, dilihat dari sudut pandang pragmatis (konteks), pascakolonialitas yang melekat pada karya sastra pascakolonial Indonesia pada dasarnya merupakan kode khas yang disampaikan atau direpresentasikan oleh pengarang dalam karya ciptanya, dan hasil representasi itu oleh pembaca dapat digunakan sebagai referensi untuk melahirkan berbagai gagasan (ideologi) tematis tertentu. Gagasan tematis yang muncul dari relasi kuasa adalah sikap demokratis, cinta damai, dan peduli sosial. Gagasan tematis yang lahir dari identitas ganda adalah sikap toleran, menghargai (prestasi) orang lain, dan tanggung jawab. Gagasan tematis yang muncul dari usaha peniruan adalah tindakan rasa ingin tahu, kerja keras, kreatif, disiplin, dan mandiri. Gagasan tematis yang dapat dipetik dari resistensi adalah membangun semangat kebangsaan dan cinta tanah air.

Sementara itu, berbagai gagasan tematis tersebut oleh pembaca dapat pula dijadikan sebagai proyeksi bagi dirinya dalam rangka pembinaan dan pengembangan diri (manusia, bangsa) yang berkarakter. Oleh karena itu, pantas untuk ditegaskan bahwa di Indonesia karya-karya (dan berbagai kajian) sastra pascakolonial perlu dipertimbangkan sebagai bagian penting dalam dunia pendidikan seperti halnya di Amerika karena pengalaman kolonial tidak lain adalah pengalaman pahit yang bersifat menyadarkan. 


\section{Daftar Pustaka}

Allen, Pamela. 2004. Membaca dan Membaca Lagi: Reinterpretasi Fiksi Indonesia 1980--1995. Diterjemahkan oleh Bakdi Sumanto dari buku Reading Matters: An Examination of Plurality of Meaning in Selected Indonesian Fiction 1980--1995 (1999). Magelang: Indonesia Tera.

Andreotti, Vanessa. 2011. Actionable Postcolonial Theory in Education. New York: Palgrave MacMillan.

Arthur, James. 2003. Education with Character: The Moral Economy of Schooling. London and New York: Routledge.

Ashcroft, Bill, Gareth Griffiths, Helen Tiffin. 2003. Menelanjangi Kuasa Bahasa: Teori dan Praktik Sastra Pascakolonial. Diterjemahkan oleh Fati Soewandi dan Agus Mokamat dari buku The Empire Writes Back: Theory and Practice in Post-colonial Literatures (1989). Yogyakarta: Kalam.

Bhabha, Homi K. 1994. The Location of Culture. London and New York: Routledge.

Bogaerts, Els. 2011. "Ke Mana Arah Kebudayaan Kita? Menggagas Kembali Kebudayaan di Indonesia pada Masa Dekolonisasi." Dalam Lindsay, Jennifer dan Maya H.T. Liem (Ed.). Ahli Waris Budaya Dunia: Menjadi Indonesia 1950--1965. Bali/Jakarta: Pustaka Larasan/KITLV.

Cooper, Karyn and Robert E. White. 2012. Qualitative Research in the Post-Modern Era. London and New York: Springer.

Darma, Budi. 1995. Harmonium. Yogyakarta: Pustaka Pelajar.

Eco, Umberto. 1976. A Theory of Semiotics. Bloomington: Indiana University Press.

Faruk. 2001. Beyond Imagination: Sastra Mutakhir dan Ideologi. Yogyakarta: Gama Media. --. 2007. Belenggu Pasca-Kolonial: Hegemoni dan Resistensi dalam Sastra Indonesia. Yogyakarta: Pustaka Pelajar.

Gardner, Roy, Jo Cairns, and Denis Lawton. 2005. Education for Values: Morals, Ethics, and Citizenship in Contemporary Teaching. London and USA: Kogan Page Limited.

Kartodirjo, Sartono dkk. 1975. Sejarah Nasional Indonesia (Jilid V). Jakarta: Departemen Pendidikan dan Kebudayaan.

Kozlowski, Darrell J. 2010. Key Concepts in American History: Colonialism. New York: Chelsea House Publisher.

Krippendorff, Klaus. 2004. Second Edition. Content Analysis: An Introduction to Its Methodology. California: Sage Publications, Inc.

Leonard, Philip. 2005. Nationality Between Poststructuralism and Postcolonial Theory: A New Cosmopolitanism. New York: Palgrave Macmillan.

Lo, Jacqueline and Helen Gilbert. 1998. "Postcolonial Theory: Possibilities and Limitations." Paper in An International Research Workshop, University of Sidney, May 29--31, 1998.

Loomba, Ania. 2003. Kolonialisme/Pascakolonialisme. Diterjemahkan oleh Hartono Hadikusumo dari buku Colonialism/Postcolonialism (Routledge, New York, 2000). Yogyakarta: Bentang Budaya.

Noor, Rusdian. 2002. "Mimikri dan Resistensi Radikal Pribumi terhadap Kolonialisme dalam Roman Bumi Manusia Karya Pramoedya Ananta Toer." Tesis S-2 Program Pascasarjana UGM.

Pemerintah Republik Indonesia. 2010. Kebijakan Nasional Pembangunan Karakter Bangsa Tahun 2010--2025. Jakarta: Pemerintah RI.

Said, Edward W. 2010. Orientalisme: Menggugat Hegemoni Barat dan Mendudukkan Timur sebagai Subjek. Diterjemahkan oleh Ahmad Fawaid dari buku Orientalism (1978). Yogyakarta: Pustaka Pelajar.

Sayuti, Suminto A.. 2003. Taufiq Ismail dalam Konstelasi Pendidikan Sastra. Yogyakarta: Universitas Negeri Yogyakarta.

Segers, Rien T. 2000. Evaluasi Teks Sastra. Diterjemahkan oleh Suminto A. Sayuti dari buku The Evaluation of Literary Texts (1978). Yogyakarta: Adicita Karya Nusa.

Seung, T.K. 1982. Semiotics and Thematics in Hermeneutics. New York: Columbia University Press.

Simbolon, Parakitri T. 2006. Menjadi Indonesia. Jakarta: Penerbit Buku Kompas.

Stake, Robert E. 2010. Qualitative Research Studying How Things Work. New York and London: The Guilford Press.

Sugiarti, Yati. 2005. "Identitas dan Mimikri dalam Roman Salah Asuhan Karya Abdoel Moeis." Tesis S-2 Program Pascasarjana UGM.

Toha-Sarumpaet, Riris K. 2010. Edisi Revisi. Pedoman Penelitian Sastra Anak. Jakarta: Yayasan Pustaka Obor Indonesia. 


\title{
PERIBAHASA BANJAR (MENAMPILKAN KARAKTER NEGATIF UNTUK PENDIDIKAN KARAKTER POSITIF)
}

\author{
H. Rustam Effendi \\ Universitas Lambungmangkurat, Banjarmasin \\ rustameffendi@yahoo.co.id
}

\begin{abstract}
Abstrak
Apabila berbicara tentang karakter, peribahasa (termasuk peribahasa Banjar) merupakan wadah yang paling efektif dan paling sering diungkapkan untuk menanamkan nilai karakter. Dilihat dari sisi bentuk, peribahasa Banjar dapat dipilahkan menjadi dua tipe, yakni tipe yang mendeskripsikan/menampilkan manusia berkarakter ideal (karakter positif) dan menampilkan manusia yang sama sekali tidak berkarakter dan atau mengabaikan karakter atau akarakter (karakternegatif). Walaupun dua tipe ini tampaknya berseberangan, tujuannya sama, yakni menanamkan nilai-nilai karakter yang ideal kepada anggota masyarakatnya. Artikel ini hanya menyoroti salah satu dari dua tipe di atas, yakni tipe peribahasa yang menampilkan sosok manusia yang akarakter dan pesan-pesan moral yang terkandung di dalam peribahasa itu. Tipe peribahasa ini lebih banyak jumlahnya dibandingkan dengan tipe pertama. Masyarakat juga lebih menyukai tipe ini dalam menyampaikan pesan-pesan moral. Masyarakat Banjar lebih sering menggunakan tipe peribahasa ini disebabkan (a) dapat dijadikan bahan bercanda atau bahan tertawaan, (b) lebih konkret sehingga mudah dipahami, (c) mudah diingat karena acuannya jelas, (d) mengingatkan sejak dini sebelum pelanggaran nilai terjadi, dan (e) berisi kritik yang pedas yang sasarannya berlaku umum.
\end{abstract}

Kata kunci: Peribahasa Banjar, Karakter ideal, akarakter

\begin{abstract}
Proverb can be said as an effective and common tool for educating the character values. In term of form, Banjarese proverb can be divided into two types: (1) a type that describes a people who has a good or ideal values (positive characters), and (2) a type of people who does not have any values at all (negative characters). It seems that these types are cross aside, but in reality, these two types actually have the same purpose which is educating good characters for our society. This article talks about one type of those types, which is a type of Banjarese proverb that displaying the negative characters for educating the positive moral values (positive characters). This type of proverb has a lot in numbers, and mostly the society likes this type of proverb more than the first ones. This may be understood because (1) this type of proverb can be act a humorous thing to be discussed, (2) it is more factual so it is easy for the society to understand the meaning of the proverb itself, (3) it is easy to be remembered as it has a clear point, (4) it acts as an early awareness, and (5) it contains a strong critical point for the public community.
\end{abstract}

Keywords: Banjarese proverb, positive characters, negative characters 


\section{Pendahuluan}

Peribahasa Banjar adalah salah satu jenis tradisi lisan yang dihasilkan oleh masyarakat tradisional Banjar. Peribahasa Banjar pernah mengalami masa jayanya pada zamannya. Bahkan, saat ini pun, peribahasa Banjar yang merupakan warisan budaya nenek moyang itu masih digunakan pada kesempatan tertentu (seperti bakisah 'bercerita', bapidatu 'taklimat pambakal/kepala kampung', dan bantaran pangantin 'mengantar pengantin ke rumah mertua. Kridalaksana (1993) mengemukakan bahwa peribahasa (saying, maxim) adalah kalimat atau penggalan kalimat yang telah membeku bentuk, makna, dan fungsinya dalam masyarakat. Karena sifatnya yang sudah membeku, bentuk, makna, dan fungsi peribahasa telah juga membeku dalam benak masyarakat. Bentuk, jumlah peribahasa relatif tetap. Kalau ada perubahan bentuk, perubahan itu hanya variasi belaka, sedangkan makna dan fungsinya tidak berubah, yakni sebagaimana masyarakat pemilik peribahasa itu memaknai dan memungsikan peribahasa itu.

Peribahasa Banjar seperti juga bentuk karya sastra tradisional yang lain memiliki berbagai fungsi (bandingkan dengan Dharmojo, 2005). Salah satu fungsi peribahasa (yang dibahas dalam artikel ini) adalah sebagai papadah sabalum bakajadian 'nasihat sebelum hal buruk terjadi). Peribahasa ini perlu diketengahkan karena sebagian besar peribahasa Banjar berisi deskripsi tentang sifat/ karakter manusia yang tercela. Sudah tentu, tujuan mendeskripsikan sifat manusia yang tercela bukan untuk mencontoh sifat itu, tetapi adalah untuk menghindari sifat buruk itu.

Manusia dan alam sekitar tidak dapat dipisahkan, bahkan, manusia dan alam sekitar menjadi sumber penciptaan karya-karya budaya. Saidatul Nornis Hj. Mahali \& Mohd. Rasdi Saamah (2013) yang meneliti peribahasa orang Semai mengemukakan bahwa sebagai kaum penghuni hutan, mereka banyak menggunakan lingkungan alam sebagai perbandingan terhadap sifat dan kelakuan manusia. Khazanah hutan yang kaya menyebabkan kiasan bahasa milik kaum Semai merujuk kepada sifat hewan sebagai bahan persamaan dan perbandingan dengan sifat manusia. Zainal Azma Zainon Hamzah \& Ahmad Fuad Mat Hassan (2011) mengemukakan bahwa peribahasa dapat menjadi gambaran nilai sosial, nilai moral, dan fungsi adat dalam kehidupan bermasyarakat sekaligus menonjolkan falsafah suatu bangsa yang berkaitan dengan metafisik, epistimologi, etika, logika, dan estetika hasil interaksi mereka terhadap alam benda, alam flora dan fauna yang ada di sekeliling mereka. Peribahasa Banjar sebagai karya budaya masyarakat Banjar juga tidak terlepas dari pengalaman mereka berinteraksi dengan alam tumbuhan, hewan, dan perangai manusianya. Alam tumbuhan, hewan, manusia dan perangainya menjadi simbol untuk melukiskan karakter manusia (bandingkan dengan Dharmojo, 2005; Djoko Damono, dkk., 2010).

Apabila dilihat dari sisi bentuk, peribahasa Banjar dapat dipilahkan menjadi dua tipe, yakni peribahasa yang menampilkan sosok manusia berkarakter ideal dan manusia yang akarakter (bandingkan dengan Zuchdi, Kun Prasetya \& Siasah Masruru, 2013; Lickona, 1991; Lickona, 2001). Begitu pentingnya pengenalan terhadap berbagai tipe karakter (karakter ideal dikenali untuk diamalkan dan karakter jelek untuk dihindari) maka dewasa ini persoalan karakter menjadi bagian yang tidak terpisahkan dari kurikulum sekolah (Rohman, 2012; Kesuma,Triatna, Permana, 2011; Lickona, Schaps, Lewis, 1995). Walaupun dua tipe ini tampaknya berseberangan, tujuan keduanya sama, yakni ingin menyampaikan gambaran sosok karakter yang didambakan oleh masyarakat Banjar. Peribahasa yang sarat dengan nilai karakter menjadi media pendidikan dan sekaligus menjadi rujukan, rambu-rambu, dan pemandu dalam berprilaku dan berinteraksi dalam kehidupan bermasyarakat.

Peribahasa Banjar buyut $k a$ intah kaganangan urang 'dari buyut hingga ke intah tidak terlupakan orang.' adalah contoh peribahasa Banjar yang menampilkan sosok manusia ideal. Menurut peribahasa ini, seseorang harus berbuat baik sepanjang hayatnya. Perbuatan yang terbaik itu akan berkesan dan tidak akan terlupakan sampai kapan pun. Buyut 'anak dari cucu' dan intah 'satu tingkat di bawah cucu/anak dari buyut' merupakan simbol suatu perbuatan baik yang dilakukan oleh seseorang dan perbuatan baik itu tidak pernah akan terlupakan sepanjang hayat. Kebalikan dari peribahasa ini adalah takulih tahi larut 'terperhatikan tahi larut.' Peribahasa ini menggambarkan buruknya perilaku dan atau pekerjaan seseorang sehingga masyarakat sangat enggan melihat orang itu. Masyarakat membandingkan orang itu dengan tahi larut 'tinja yang larut di permukaan sungai,' dan tahi larut lebih berharga dibanding dengan manusia itu. 


\section{Gambaran Manusia Akarakter Dalam Peribahasa Banjar}

Dalam peribahasa Banjar ditampilkan dua sosok manusia yang memiliki karakter berseberangan, yakni manusia yang berkarakter ideal dan manusia yang sama sekali tidak berkarakter (akarakter). Ukuran manusia ideal dan manusia akarakter tentu menurut pandangan dan penilaian masyarakat Banjar secara turun temurun, dari generasi ke generasi. Ukuran penilaian tentang manusia ideal dan manusia akarakter dapat ditelusuri dari folklor yang diwariskan oleh masyarakat Banjar dari satu generasi ke generasi berikutnya. Ukuran itu akan tetap tidak berubah selama folklor masyarakat itu terjaga dan selalu diingatkan oleh tetuha masyarakat pada saatsaat tertentu. Di dalam folklor itulah cara berpikir, berprilaku, dan berkarya masyarakat terekam dan menjadi pedoman berkehidupan.

Peribahasa Banjar merupakan wadah yang sangat efektif untuk menyampaikan pesanpesan moral. Peribahasa mudah diingat karena bentuknya yang singkat dan sangat cocok dengan alam berpikir masyarakat Banjar. Masyarakat Banjar tradisional yang pada umumnya petani dan pedagang memerlukan pesan moral yang cepat, ringkas, mengena, yang dijadikan sebagai bekal dalam melakoni pekerjaannya. Sebagai petani, mereka bergaul dengan petani lainnya dan saling tolong-menolong 'gotong royong' dalam mengerjakan sawah atau kebun. Sebagai pedagang, mereka bergaul dengan sesama pedagang dan dengan pembeli. Dalam pergaulan itu, mereka harus memegang pesan nenek moyang, seperti yang dilukiskan oleh peribahasa duit cacarian 'uang bisa dicari'. Peribahasa ini maksudnya kekeluargaan dan persahabatan lebih penting dari uang yang dicari. Berdagang dan apapun pekerjaan yang dilakoni harus mendahulukan dan mementingkan hubungan mesra sesama manusia, bukan karena ambisi terhadap duit lalu hubungan antarsesama menjadi renggang.

Satu hal yang khas dalam peribahasa Banjar adalah bahwa peribahasa Banjar lebih banyak menampilkan sosok manusia yang akarakter/ amoral. Bentuk ini sangat disukai karena: (a) dapat dijadikan bahan bercanda atau bahan tertawaan, (b) lebih konkret sehingga mudah dipahami, (c) mudah diingat karena acuannya jelas, (d) mengingatkan sejak dini sebelum pelanggaran nilai terjadi, dan (e) berisi kritik yang pedas yang sasarannya berlaku umum. Peribahasa bungul pada kalum 'lebih bodoh daripada kalum' (kalum adalah sandal yang terbuat dari kayu), bagi masyarakat Banjar, peribahasa ini berisi suatu pernyataan yang lucu, konkret, acuan yang jelas, alat pengingat agar menghindar dari perilaku yang konyol, serta sekaligus berisi kritik terhadap perilaku seseorang yang sangat bodoh. Kata bungul 'bodoh' apabila diucapkan bukan pada waktu sedang marah, misalnya saat bercanda atau bergurau di warung kopi, kata bungul mengundang rasa geli dan membuat orang yang mendengar tertawa. Kata kalum pada peribahasa ini menjadi simbol manusia yang lemah, rendah, tidak berdaya, dan tersia-sia karena kebodohannya. Bagi masyarakat Banjar, kata kalum beserta sifatsifatnya sangat konkret. Jadi, kalau seseorang dikatakan bungul pada kalum berarti orang itu adalah orang bodoh sebodoh-bodohnya.

\section{1) Manusia Akarakter}

\section{Manusia yang culas}

Salah satu peribahasa Banjar yang menggambarkan seseorang yang culas adalah Akal nang kaya Sarawin 'seperti akal Sarawin.' Sarawin adalah nama tokoh fiksi dalam dongeng Banjar. Sarawin digambarkan sebagai seorang yang banyak akal dan menghalalkan segala cara untuk mencapai tujuan. Untuk mengelabui orang lain, Sarawin beraksi yang membuat orang-orang tertawa, terperanjat, dan kecewa. Yang penting, tujuan untuk memperoleh sesuatu tercapai. Dalam satu episode, Sarawin berterik di depan rumah orang yang kenduri. Katanya, "Ular! Ular! Ular!" Semua orang yang ada di dalam rumah itu keluar dengan kayu pemukul. Namun, ular itu tidak ada karena teriakan itu hanya satu strategi agar dia dapat ikut makan di tempat orang yang kenduri itu. Akhirnya, Sarawin diajak naik ke rumah orang kenduri dan ikut makan di sana. Hingga sekarang, apabila ada orang yang datang ke tempat orang kenduri tanpa diundang disebut manyarawin 'berbuat seperti Sarawin.' Dengan tabiat seperti ini, tokoh Sarawin bukan tokoh ideal, tetapi tokoh yang menjadi contoh seorang manusia tidak pantas ditiru. Dalam bahasa Banjar, kata akal memiliki dua kutub makna yang berseberangan, yakni akal bermakna positif, seperti pada kata akalan 'pandai memecahkan masalah,' baakal 'berakal,' dan bermakna negatif, seperti maakali kawan 'menipu kawan.' akal barangkap. Dalam konteks ini, Sarawin lebih banyak menggunakan akalnya untuk mengakali orang lain. 
Peribahasa lain yang menggambarkan manusia yang culas adalah ia banar akal Cina 'persis sekali akal Cina.' Sebagian masyarakat Banjar menganggap etnik Cina (tentu tidak semua Cina) sebagai etnik yang pintar dan licik. Etnik Cina disimbolkan sebagai etnik yang pintar di samping juga licik dalam berniaga. Mungkin peribahasa ini bersumber dari pengalaman satu-dua orang masyarakat Banjar yang sering berhubungan dengan seorang etnik Cina yang kebetulan culas atau mungkin juga bersumber dari kabar burung yang tidak jelas sumbernya. Kabar burung itu lalu dikabarberitakan dan dibenarkan tanpa reserve oleh masyarakat Banjar lainnya. Dengan demikian, satu-dua orang Banjar yang berhubungan dengan satu-dua orang Cina yang 'culas' digemakan (oleh orang Banjar itu) ke mana-mana. Pengalaman berhubungan dengan etnik lain (etnik asing) merupakan pengalaman luar biasa sehingga menjadi bahan cerita yang menarik. Oleh karena itu, pengalaman satu-dua orang ini diterima sebagai pengalaman yang unik dan menjadi pengalaman kolektif (masyarakat).

\section{2) Manusia yang hanya pandai membual}

Manusia yang hanya pandai membual dilukiskan oleh peribahasa amun bapandir, langit handak digulung 'Kalau berkata-kata langit ingin digulung.' Peribahasa ini melukiskan seseorang yang hanya 'raja bicara'. Pada awalnya, orang terpesona dengan keahliannya menyampaikan pendapat, mengeritik, dan bahkan memerovokasi masyarakat. Di mana-mana keberadaan orang ini menjadi titik perhatian. Namun, lama-kelamaan masyarakat jenuh mendengarkan bicaranya karena ternyata orang itu hanya pandai berbicara, teori melulu, sedangkan bukti gawiannya 'pekerjaannya' lebih jelek dari yang lain. Akhirnya orang ini disindir oleh masyarakat dengan peribahasa, Lancar pandir, bahira mucir 'lancar kata berak tercecer-cecer'. Kata bahira 'berak' menyimbolkan perbuatan kotor dan mucir yang berarti perbuatan kotor itu tersebar ke manamana. Anggota masyarakat yang dilukiskan oleh peribahasa ini adalah sosok manusia yang tidak boleh dijadikan contoh. Manusia yang baik bukan manusia seperti yang dilukiskan oleh peribahasa di atas tetapi oleh peribahasa seperti kawa baucap, kawa manggawi, kawa manyandang 'bisa berkata, bisa melakukannya, dan sanggup menanggung risikonya'. Peribahasa ini menggambarkan bahwa perilaku yang ideal adalah perilaku orang yang tidak hanya pandai berbicara atau berteori, tetapi juga pandai mengerjakan dan tidak mengeluh karena beban pekerjaan itu. Masyarakat Banjar sangat mencela orang yang senang membual atau berbicara lantang apalagi orang itu tidak dapat membuktikan bualannya itu. Masyarakat Banjar sangat menghargai orang yang tidak terlalu banyak berbicara tertapi dapat menunjukkan hasil pekerjaan yang positif. Menurut masyarakat Banjar, dalam berbicara seseorang lebih baik barandah-randah pada kancur 'merendah lebih rendah dari kencur.' Kencur adalah tanaman rempah yang sangat rendah. Rendahnya tanaman ini menyimbolkan kerendahan hati seseorang.

\section{3) Manusia yang kikir dan mau menang sendiri}

Salah satu peribahasa Banjar yang melukiskan sifat kikir adalah kada titik banyu diganggam 'tidak menetes air di genggaman.' Peribahasa ini melukiskan seorang yang sangat kikir, pelit, dan individualis. Orang ini hampir tidak memiliki kepedulian terhadap masyarakat di lingkungannya. Masyarakat Banjar tradisional yang mengedepankan gotong royong, siap membantu tetangganya tanpa pamrih, baik bantuan tenaga maupun materi, tidak berlaku pada orang ini. Apabila ada orang baarian 'gotong royong saat mengerjakan sawah atau mengetam padi' orangorang berdatangan dengan suka cita sedangkan dia berpura-pura tidak tahu dan tidak datang ke tempat orang baarian itu. Namun, apabila gotong royong untuk mengerjakan sawahnya, ia sangat mengharapkan kedatangan orang lain. Apabila pada saat baarian orang menyiapkan jamuan yang memuaskan, ketika baarian di tempatnya, dia hanya menyiapkan jamuan seadanya. Orang kikir, pelit, dan individualis sangat apik dengan harta bendanya. Harta benda yang ada di tangannya sangat sulit ke luar dari genggamannya, walaupun itu untuk kepentingan sosial yang akan dinikmati bersama-sama. Orang ini penuh perhitungan dan apabila mengeluaran sesuatu dari genggamannya pastilah pengeluaran itu lebih banyak menguntungkan dirinya. Harta benda yang berada di tangannya digenggamnya erat-erat, begitu eratnya sehingga air pun apabila berada di genggaman tangannya tidak

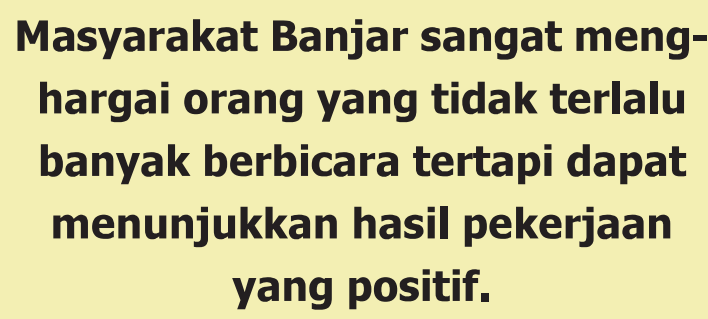


akan dapat menetes. Hal ini berarti masyarakat tidak dapat mengharapkan partisipasi apa pun dari orang ini.

Peribahasa lain yang melukiskan seorang manusia yang kikir adalah tangga saurang disintak tangga urang dikair 'Tangga sendiri ditarik, tangga orang lain diambil.' Peribahasa ini melukiskan tentang sifat seseorang yang kikir. Kata tangga menyimbolkan benda dan atau apa saja yang bernilai. Tangga urang disintak bermakna mengharap dan mencari-cari kebaikan dan atau pemberian orang lain, tetapi dia sendiri sangat enggan memberi sesuatu kepada orang lain. Sangat banyak ungkapan Banjar yang berhubungan dengan sifat kikir seseorang. Di antaranya juga ingkin barajut 'sangat kikir'. Ungkapan ini hampir sama dengan ungkapan di atas, yakni melukiskan sifat kikir yang keterlaluan. Peribahasa ini merupakan peringatan kepada warga masyarakat agar jangan kikir dan jangan mau menang sendiri. Peribahasa ini juga mengajarkan agar warga masyarakat saling membantu dan jangan merugikan orang lain.

Sifat manusia yang kikir atau mau menang sendiri dilukiskan pula oleh peribahasa dibawa malinggang jukung ditinggal manawaki 'apabila dibawa menggoyang jukung dan apabila ditinggal melempari orang yang ada di dalam jukung.' Peribahasa ini menggambarkan manusia yang tidak bisa hidup bermasyarakat, egoismenya sangat tinggi, dan mau menang sendiri. Apabila diajak bermusyawarah, dia enggan menyetujui hasil musyawarah. Sementara itu, apabila tidak diajak bermusyawarah, dia meneror orang lain yang ikut dalam musyawarah. Peribahasa ini bernuansa kehidupan pedesaan yang mengandalkan jukung sebagai alat transportasi. Jukung digunakan untuk mengunjungi keluarga dari rumah ke rumah, sarana untuk menuju tempat bekerja, dan berniaga. Jukung juga menjadi alat transportasi umum seperti layaknya bus di daratan. Beranjak dari pengalaman mengarungi sungai dengan jukung terbentuklah satu peribahasa di atas. Orang egoisme digambarkan sebagai orang yang membuat masyarakat tidak tenteram. Orang ini apabila diajak bersama, ulahnya tidak lain hanya membangkang sehingga sesuatu yang dinginkan bersama menjadi buyar. Namun, apabila orang ini tidak diajak bersama, dia mengumpat-umpat dan mengganggu dengan berbagai cara sehingga segala rencana menjadi gagal.

\section{4) Manusia yang lupa diri}

Di antara peribahasa yang menggambarkan manusia yang lupa diri adalah cancut naik $k a$ sampiran 'cancut naik ke jemuran' Peribahasa ini melukiskan tabiat orang yang pongah, lupa diri, terlampau membanggakan diri. Orang yang bertabiat semacam ini diibaratkan cancut naik ka sampiran. Cancut adalah kain pembalut kemaluan wanita saat mentruasi (kain pembalut wanita). Darah kotor yang ke luar terserap oleh kain itu. Cancut diambil dari kain lama yang tidak terpakai lagi. Wanita sangat hati-hati meletakkan cancut agar orang lain tidak mengetahuinya. Wanita Banjar tradisional yang normal sangat malu apabila cancutnya dilihat oleh orang lain, sekalipun yang melihat itu adalah ibu atau saudaranya sendiri. Di samping kotor, cancut juga menjadi rahasia pribadi seorang wanita. Cancut yang kotor yang diletakkan di pojok-pojok tersembunyi kini berada di sampiran bersama pakaian lain yang bagus-bagus. Sampiran (dalam bahasa Banjar kata sampiran bersinonim dengan dadaian) adalah tali jemuran yang terikat di antara dua tiang atau pohon yang membentang di samping atau di depan rumah. Di atas tali jemuran itu biasanya para wanita menjemur pakaiannya hingga kering. Cancut atau kain kotor yang terpajang di sampiran bersama kain bersih lainnya melambangkan seseorang yang lupa diri. Mungkin orang ini dahulunya sangat miskin, kemudian mendapatkan harta yang melimpah sehingga kelakuannya tidak terkontrol lagi. Orang ini lupa pada awal kehidupannya, lupa untuk apa dia hidup, dan lupa pula tentang kesudahan hidup, yaitu kematian.

Peribahasa lain yang melukiskan seseorang yang lupa diri adalah kaya bagung jadi raja, baras dihampalas 'seperti bagong menjadi raja, beras pun diempelas.' Peribahasa ini mengambil tokoh fiktif Bagong dalam cerita wayang. Karakter Bagong yang arogan dan tidak bernalar disamakan dengan seorang manusia dalam dunia fakta. Bagong adalah seorang abdi kerajaan yang sangat loyal terhadap raja. Namun, pada suatu ketika, karena satu dan lain hal, raja tidak ada dan Bagong menjadi raja. Karena asal-muasalnya seorang abdi rendahan, cara berpikirnya pun tidak proporsional dan tidak profesional. Bagong hanya tahu bahwa raja dapat berbuat sesukanya. Oleh karena itu, atas nama kekuasaan, Bagong berbuat apa saja sampai-sampai beras pun mau diempelas. 


\section{5) Manusia yang gegabah}

Usaha yang dilakukan tanpa ilmu, tanpa perhitungan, gegabah, tidak saja menyebabkan usaha itu gagal mencapai tujuannya, tetapi lebih dari itu, segalanya menjadi berantakan sehingga tidakadaharapanuntukmemulainya lagi.Salah satu peribahasa yang menggambarkan sifat manusia ini adalah cubik ramuk balanai pacah 'cobek remuk belanai pecah.' Peribahasa ini melukiskan pekerjaan atau usaha yang sangat sia-sia. Bagi kaum perempuan, cubik dan balanai merupakan alat rumah tangga yang sangat penting. Dengan cubik dan belanai itulah, para kaum perempuan melakukan tugas sehari-harinya sebagai juru masak di dalam rumah tangga. Berbagai rempahrempah dapur, seperti kunyit, garam, gula merah, lombok, dan lain-lain dipadukan dan dimasukkan ke dalam balanai. Semua rempah-rempah itu kemudian dipirik 'dilindas' dengan cubik. Setelah semua rempah-rempah itu menjadi halus atau lumat, jadilah sambal yang enak untuk dinikmati oleh orang-orang seisi rumah.

Pekerjaan yang sia-sia diibaratkan dengan cubik yang remuk dan balanai yang pecah. Cubik adalah alat pemirik rempah-rempah yang terbuat dari batu gunung yang kuat dan keras. Balanai adalah wadah rempah-rempah yang akan dihaluskan. Balanai terbuat dari tembikar atau tanah liat yang kuat untuk sekedar menghaluskan rempah-rempah. Untuk menghaluskan rempahrempah itu, cubik digeser-geserkan di atas rempah-rempah yang berada di dalam balanai. Para kaum perempuan sudah sangat mengetahui kemampuan balanai menahan tekanan batu cubik. Mereka tentu tidak menekan batu cubik itu terlalu keras, harus sabar, sedikit demi sedikit, pelan, dan hati-hati memainkan batu cubik itu agar balanai tidak pecah. Karena tidak hatihati, tidak sabar, terlalu keras, dan terlalu lama menghentakkan cubik, atau karena tidak terbiasa membuat sambal, bukan tidak mungkin sambal tidak menjadi, yang terlihat hanyalah cubik yang remuk dan balanai yang pecah.

Peribahasa Banjar yang lain yang bermakna kurangnya perhitungan sebelum memutuskan suatu pekerjaan adalah lanjung bubus kapayang hilang 'lanjung bolong dan buah kepayang hilang.' Peribahasa ini berisi perenungan terhadap kejadian yang menimpa seseorang. Seseorang ini menemui kegagalan meraih cita-cita karena terlalu berambisi dan tidak mempertimbangkan kemampuan dirinya. Cita-cita yang tinggi yang diangan- angankan jangankan bisa diraihnya bahkan apa-apa yang telah dimiliki sebelumnya habis semuanya. Kata lanjung (ransel besar yang terbuat dari rotan yang dihela di kedua bahu) diibaratkan telah berisi dengan hasil jerih lelah sesuai kemampuannya namun orang ini tidak merasa puas dan ingin sesuatu yang lebih banyak lagi. Sesuatu yang lebih besar itu diibaratkan dengan buah kapayang. Buah kapayang adalah buah yang memabukkan. Karena cita-citanya terlalu tinggi dan tidak sesuai dengan kemampuan dirinya, yang terjadi adalah lanjung yang telah berisi jerih lelahnya terdahulu bobol sehingga semuanya berjatuhan dan hilang serta buah kapayang (simbol cita-cita yang tinggi) yang diidam-idamkannya tidak pernah kunjung terwujud.

\section{6) Manusia yang tidak pandai menghargai jasa orang lain}

Salah satu peribahasa yang menggambarkan manusia yang enggan menghargai jasa orang lain adalah amun tagapit bakuciak amun dilapas maiji-iji 'kalau terjepit berteriak, kalau dilepaskan mengolok-olok.' Peribahasa ini ditujukan kepada seseorang yang tidak mau mengakui kebaikan orang lain. Orang ini, kalau mendapat kesusahan berteriak-teriak meminta tolong, tetapi, setelah ditolong sehingga berhasil ke luar dari kesusasahan, dia malah maiji-iji terhadap orang yang menolongnya. Maiji-iji adalah raut muka terutama bagian mulut yang dibuat dengan sengaja sebagai tanda mengejek seseorang. Maijiiji adalah tabiat kera atau monyet. Bagi masyarakat di pedesaan, tabiat kera atau monyet ini sangat mereka kenal. Mereka sangat hafal bagaimana raut muka monyet atau kera ketika maiji-iji 'mengolokolok' Pak Tani yang kebetulan lewat di bawah pohon tempat kera atau monyet itu berada. Kera atau monyet itu seolah mengolok-olok Pak Tani yang tidak dapat mengejarnya karena mereka berada di atas pohon yang tinggi dan aman. Dalam fabel Banjar, monyet diceritakan sebagai binatang yang culas. Ketika ekor monyet terjepit batang pohon, dia berteriak-teriak kesakitan dan memohon pertolongan binatang lain. Namun, setelah terlepas dari jepitan itu, dia secepat kilat lari ke atas pohon dan maiji-iji binatang yang telah menolongnya itu. Demikianlah, peribahasa ini mengibaratkan seseorang yang tidak berterima kasih seperti perilaku seekor kera atau monyet. 


\section{7) Manusia yang tidak berprikemanusiaan}

Salah satu peribahasa yang melukiskan manusia yang kejam terhadap manusia lainnya adalah tabiat mambulanda 'persis seperti tabiat orang Belanda.' Mambulanda berasal bulanda 'belanda', yang berarti nama suatu bangsa, yakni bangsa Belanda yang lama menjajah bangsa Indonesia. Dalam ungkapan ini, mambulanda berarti berlaku atau bersifat seperti orang Belanda. Di mata masyarakat tradisional atau orang-orang tua yang pernah hidup dan merasakan sengsaranya masa penjajahan, Belanda merupakan sosok yang menyeramkan, gampang marah, dan penyiksa kaum pribumi. Dengan dasar pengetahuan ini, masyarakat menggeneralisasi sikap penjajah Belanda ini dengan sikap siapa saja yang kejam dan pemarah walaupun dia adalah orang pribumi. Dengan kata lain, ungkapan mambulanda menjadi ikon kebengisan, kekejaman, dan pelempiasan nafsu amarah. Orang yang bengis, kejam, pemarah disebut mambulanda. Sebaliknya, apabila kata mambulanda dikaitkan kepada nama seseorang, masyarakat sudah mengerti bahwa orang yang disebut mambulanda itu adalah orang yang bengis dan kejam. Peribahasa ini masih digunakan oleh orang-orang tua. Mungkin mereka tidak tahu bahwa sikap dan sifat Belanda sekarang sudah jauh berubah dibandingkan dengan pada masa penjajahan. Sekarang, bangsa Belanda sudah menjadi salah satu bangsa pelopor dalam memperjuangkan kemanusiaan yang beradab atau Hak Azasi Manusia (HAM).

\section{8) Manusia yang tidak berpendirian}

Salah satu peribahasa yang menggambarkan seseorang yang tidak memiliki pendirian adalah gawian mailung larut 'pekerjaan bagai ilung larut.' llung 'enceng gondok' adalah tumbuhan yang hidup di tepi-tepi sungai pasang-surut. Apabila air mulai pasang, ilung mulai beranjak larut mengikuti aliran sungai. Cukup lama ilung terombangambing oleh gelombang pasang. Setelah puluhan jam, air pasang mulai berangsur turun dan ilung pun kembali menuju ke hulu mengikuti aliran air. Seperti halnya pada waktu pasang, pada waktu pandit 'surut' ini pun, ilung terombang-ambing, terhempas ke kiri dan ke kanan, dan akhirnya terdampar di tepi sungai yang dangkal. Manusia yang hidupnya tidak mempunyai prinsip karena selalu mengikuti orang lain yang belum tentu benar dilukiskan hidup mailung larut.
Peribahasa lain yang melukiskan orang yang tidak memiliki pendirian adalah umpat kambing tumbur 'ikut lari seperti kambing lari berhamburan.' Segerombolan kambing lari berhamburan begitu dibukakan pintu pagar kandangnya oleh pemiliknya. Kambing-kambing itu seolah tidak sabar menahan lapar dan melihat alam bebas. Seekor kambing yang paling terdahulu ke luar pagar berlari cepat tanpa arah dan tujuan yang jelas, sedangkan kambing-kambing lainnya mengikuti saja kambing yang lebih dahulu ke luar itu. Seseorang yang mengikuti seseorang tanpa berpikir atau 'taklid buta' disebut umpat kambing tumbur. Kambing tumbur menjadi ikon bagi orangorang yang tidak memiliki prinsip hidup. Mereka mengikuti apa yang dikatakan atau dikehendaki orang lain tanpa mempertimbangkannya dengan matang.

\section{9) Manusia yang tidak cerdas atau bodoh}

Salah satu peribahasa banjar yang melukiskan sifat bodoh seseorang adalah anak urang dihambin anak saurang bajalan 'anak orang lain digendong, anak kandung sendiri disuruh berjalan.' Peribahasa ini menyindir orang yang bertindak salah. Tidak jarang dalam kehidupan ini seseorang dihadapkan dengan dua atau beberapa hal yang penting. Keterbatasan manusia tidak memungkinkan melakukan hal itu secara serempak bersamaan. Seseorang dituntut memilih salah satu yang paling utama untuk diprioritaskan. Anak urang menyimbolkan satu hal atau masalah dan anak saurang menyimbolkan satu masalah yang lain. Kata dihambin dan bajalan merupakan simbol sulosi pemecahan masalah. Anak yang dihambin adalah anak yang lebih disayang dibanding dengan anak yang disuruh berjalan. Ungkapan ini melukiskan kekeliruan dalam cara mengatasi masalah. Orang ini tidak menggunakan cara berpikir prioritas sehingga masalah yang kecil dapat teratasi sedang masalah yang lebih besar terbiarkan begitu saja. Tentu cara berpikir ini adalah cara yang keliru dan orang Banjar diperingatkan agar jangan seperti ini, tetapi harus menggunakan cara berpikir prioritas, yakni dimulai dengan menangani masalah yang lebih besar dan rumit baru kemudian menangani masalah lainnya sesuai prioritas. 


\section{0) Manusia yang suka berlagak dan haus pujian}

Peribahasa Banjar yang melukiskan seseorang yang senang berlagak dan haus pujian adalah apik-apik hundang tahi di kepala 'seapikapik udang, tinja (tahi) di kepala.' Hundang atau udang adalah ikan yang sangat disenangi karena enak dan gurih rasanya. Berbeda dengan ikanikan lainnya, kotoran (tahi) udang bertumpuk di kepalanya. Karena keadaannya yang demikian (tahi di kapala), ikan udang ini menjadi sarana kearifan lokal untuk menciptakan peribahasa. Ikan udang menyimbolkan seseorang yang suka mempropagandakan hasil usahanya, rumahnya, pakaiannya, tetapi masyarakat tahu bahwa semuanya itu diperoleh dengan cara yang tidak benar. Masyarakat tidak silau dan tidak terpengaruh dengan propaganda orang ini. Bahkan, mereka tertawa sinis melihat kelakuan orang ini. Orang semacam ini dilukiskan oleh masyarakat dengan peribahasa manang di surak 'hanya menang di gegap-gempita sorak-soray,' sedangkan kenyataannya, semua yang dipropagandakan itu tidak bernilai bagi masyarakat. Peribahasa apikapik hundang tahi di kapala bisa juga melukiskan suatu pekerjaan yang dilakukan oleh seseorang yang memang tidak layak melakukan pekerjaan itu, baik karena kondisi fisiknya maupun karena kemampuannya yang tidak ada. Jadi, orang ini sudah merasa melakukan suatu hal atau pekerjaan dengan apik dan cermat, karena keterbatasannya, semua yang dikerjakannya tidak sebaik apa yang seharusnya diharapkan. Walaupun demikian, karena ketidaktahuannya, orang ini tetap saja membangga-banggakan dirinya.

Peribahasa lain yang melukiskan seseorang suka berlagak adalah dasar alim buak 'memang alim buak.' Ungkapan ini melukiskan seseorang yang mengaku alim 'luas pengetahuan agama' tapi sebenarnya dia tidak alim. Ungkapan ini bertumpu pada kata buak. Buak adalah seekor burung (burung hantu) yang berbunyi nyaring pada malam hari. Bunyi burung itu adalah buaaaak; buaaaak; buaaaak; menyebut namanya sendiri atau mendeklarasikan perbawa dirinya sendiri; aku buaaaak; aku buaaaak; aku buaaaak. Fenomena hewan ini menjadi sumber kearifan lokal masyarakat guna membentuk satu ungkapan. Seseorang yang suka pergi ke manamana membual mendeklarasikan kehebatan, kemampuan, kearifan, kealiman, oleh masyarakat disebut alim buak. Burung Buak menjadi simbol

\section{Dari sejumlah anggota masyara-} kat terdapat satu atau beberapa orang yang hidupnya hanya menjadi beban masyarakat.

orang yang haus pujian, haus sanjungan, dan ingin dihargai.

\section{1) Manusia yang hanya menjadi beban masyarakat}

Dari sejumlah anggota masyarakat terdapat satu atau beberapa orang yang hidupnya hanya menjadi beban masyarakat. Salah satu peribahasa Banjar yang melukiskan manusia semacam itu adalah biar ada kada dihitung 'walaupun ada tidak dihitung.' Peribahasa ini berhubungan dengan seseorang yang hidupnya dianggap tidak berguna bagi masyarakat. Keberadaannya (biar ada) tidak akan memberikan kontribusi apa-apa bagi kemasylahatan dan atau kemajuan, bahkan kehadirannya malah menimbulkan kekhawatiran dan atau menambah berat beban masyarakat. Kehadirannya di tengah-tengah masyarakat lebih banyak membuat keonaran daripada membuat rasa damai dan tentram. Ada atau tidak ada orang itu tidak diperdulikan bahkan banyak orang yang mengharapkan ketiadaan orang itu. Peribahasa ini adalah sebagai peringatan bagi warga masyarakat agar mendidik keluarganya menjadi orang yang berguna bagi masyarakat, jangan menjadi sampah masyarakat.

Peribahasa lain yang melukiskan kualitas atau kemampuan seseorang berkontribusi positif bagi kemasylahatan hidup bermasyarakat adalah amas kada tambaga kada 'emas tidak tembaga pun tidak.' Peribahasa ini menggambarkan keberadaan seseorang yang tidak ada harganya. Emas adalah logam mulia yang sangat tinggi nilainya, sedangkan tembaga, walaupun bukan logam mulia masih ada harganya. Kata emas menyimbolkan seseorang yang ideal yang keberadaannya sangat diharapkan oleh masyarakat. Orang yang disimbolkan dengan emas sangat dihormarti oleh masyarakat karena mampu membawa masyarakat ke arah kehidupan yang lebih baik dan tentram. Hal itu disebabkan, kebijakannya dalam pergaulan seharihari. Orang yang disimbolkan dengan tembaga adalah masyarakat umum yang walaupun sangat sederhana, tetapi mau belajar dan berkarya sesuai dengan norma masyarakat dengan tidak 
melanggar aturan. Mereka juga berharga dalam perikehidupan masyarakat walaupun tidak dapat diharapkan sebagai pemimpin yang mampu membangkitkan harkat hidup masyarakatnya. Sebaliknya, orang yang amas kada tambaga kada adalah orang yang tidak bernilai atau sangat rendah nilainya. Orang itu lebih banyak membuat masyarakat resah daripada menyenangkan masyarakat. Dengan demikian, secara tersirat, peribahasa ini memperingatkan masyarakatnya terutama para orang tua agar mendidik anakanaknya menjadi warga yang berguna bagi masyarakatnya. Para orang tua tentu sangat malu apabila anaknya dianggap sebagai manusia yang amas kada tambaga kada.

\section{2) Manusia yang hanya mementingkan diri sendiri}

Manusia yang mementingkan diri sendiri atau egoisme adalah manusia yang baakar di atas haja 'berakar di atas saja.' Ungkapan ini melukiskan seseorang yang hanya mementingkan pergaulan dengan orang-orang yang penting bagi dirinya saja. Biasanya orang penting itu adalah orang kaya dan orang-orang yang memiliki kekuasaan. Orang kaya dan berkuasa didekatinya agar cita-citanya segera dapat tercapai. Orang ini mengabaikan masyarakat sekitarnya yang dianggapnya tidak akan dapat membuat cita-citanya mulus tercapai. Walau demikian, suatu saat dia akan membutuhkan masyarakat lingkungannya yang sebagian besar bukan orang kaya dan bukan pejabat yang diabaikannya itu. Apabila hal ini terjadi, masyarakat lingkungannya juga tidak akan terlalu menghiraukannya. Orang itu akan menyesal sendiri karena menjauhi masyarakat lingkungannya. Ungkapan ini memperingatkan kepada warga masyarakat agar mempererat tali silaturahim sesama warga di samping pula dengan siapa saja yang mempunyai tautan-hubungan dengan pekerjaan.

\section{3) Manusia tidak tahu diri}

Manusia yang tidak tahu diri dan atau angkuh dilukiskan oleh peribahasa mamuji pakasam saurang 'memuji pakasam sendiri.' Pakasam adalah ikan sungai yang dipermentasi dengan ragi-ragi khusus. Ikan pakasam sangat digemari oleh masyarakat Banjar. Di setiap pasar, dari dahulu, bahkan hingga sekarang, selalu ada orang yang menjual ikan pakasam. Konon kabarnya, pakasam yang terkenal dan enak itu adalah pakasam Barabai. Pakasam diolah oleh para kuliner pakasam berbakat. Tidak hanya satu orang yang membuat pakasam tetapi banyak orang yang berbakat membuat pakasam. Bahkan, konon ada kampung yang sebagian masyarakatnya mengkhususkan pekerjaannya membuat pakasam. Sebagai karya rumahan (home industry) rasa pakasam yang diolah oleh yang satu orang tentu berbeda dengan orang lainnya, tergantung keahlian dan pengalaman kulinernya. Pakasam menjadi mahakarya (karya yang bernilai luar biasa) karena sangat digemari oleh semua lapisan masyarakat. Sebagai mahakarya, para pembeli yang telah merasakan enaknya pakasam akan selalu datang ke pasar untuk mencari pakasam kegemarannya. Para pedagang pakasam lebih banyak menunggu reaksi pelanggannya. Biasanya pelanggan yang merasakan gurihnya pakasam yang diolah oleh pedagang $A$ akan datang lagi ke pedagang A itu. Walau demikian, ada juga pedagang yang kurang laku, kurang dikunjungi pelanggan sehingga dia berkata dengan memujimuji pakasam olahannya itu, seperti katanya, "Su, tukari pang pakasamku ini, nyaman banar pian. Samunya banyak, iwaknya ganal-ganal, nyaman tupang Pian." (Paman, Belilah pakasam yang saya buat ini, enak sekali. Bumbunya banyak, ikannya besar-besar, pendeknya sangat enak.) Kata-kata pedagang ini sangat asing terdengar oleh telinga karena pada umumnya para pedagang sangat tabu memuji hasil karyanya. Karena itu, pedagang ini dikatakan mamuji pakasam saurang. Dalam peristiwa jual-beli, masyarakat Banjar sangat tidak suka terhadap orang yang memuji-muji karya atau barang dagangannya sendiri. Memang suatu kenyataan, karya atau barang yang dipuji-puji pedagangnya sendiri biasanya berkualitas rendah. Peribahasa ini mengajarkan satu budaya atau etika jual beli dan atau etika terhadap kepemilikan umumnya. Seseorang jangan sekali-kali memuji karya atau barang sendiri, baik berupa barang dagangan maupun barang milik sendiri lainnya karena yang paling berhak memuji milik kita itu bukan diri kita tetapi adalah orang lain.

\section{4) Manusia yang malas}

Di antara peribahasa Banjar yang melukiskan manusia yang malas adalah kaya sawa mamburuki talanan 'Seperti ular piton membusukkan binatang yang ditelan.' Ular sawa 'piton' memangsa binatang perburuannya dengan cara ditelan bulat-bulat. Ular piton yang besar dapat 
menelan seekor rusa atau babi. Setelah menelan mangsanya, ular piton tinggal di liangnya atau di semak belukar beberapa lama untuk merasakan nikmat dan kenyangnya perut. Selama makanan yang ditelannya masih ada dan belum membusuk di dalam perutnya selama itu pula ular itu tinggal bermalas-malasan. Semakin hari makanan yang ditelannya semakin membusuk dan semakin habis diserap oleh tubuhnya. Apabila makanan ini semua telah terserap oleh tubuhnya dan habis dikeluarkannya menjadi kotoran maka perutnya yang besar mulai kempis dan dia mulai merasakan lapar lagi. Perasaan lapar membuatnya terbangun dan mulai berburu mencari mangsa lagi. Apabila mangsa itu telah diperolehnya maka ia pun kembali tinggal di liangnya bermalas-malasan. Sifat ular piton yang bermalas-malasan setelah menelan mangsanya menjadi inspirasi bagi masyarakat Banjar untuk mengungkapkan sifat seseorang yang cepat puas dengan hasil pekerjaan yang diperolehnya. Apabila telah memperoleh hasil dari pekerjaannya, orang ini tidak mau lagi bekerja. Orang ini hanya duduk berpangku tangan menikmati hasil pekerjaannya. Apabila hasil pekerjaannya telah habis maka ia pun kembali lagi bekerja. Jadi, orang yang malas bekerja disamakan dengan sifat seekor ular piton. Sifat ular piton yang malas setelah menelan mangsanya telah menjadi pengalaman dan pengetahuan setiap orang Banjar. Penyamaan sifat ini dapat diterima oleh setiap orang Banjar. Dengan kata lain, ular piton yang 'mamburuki talanan' mempunyai persamaan yang jelas dengan seorang yang pemalas.

\section{Penutup}

Peribahasa Banjar merupakan khazanah sastra Banjar yang sarat dengan nilai budaya. Seperti halnya peninggalan budaya masyarakat tradisional lainnya, peribahasa Banjar juga sudah mulai tergerus karena kehadiran budaya modern. Peribahasa Banjar hari demi hari, tahun demi tahun, semakin terlupakan. Apabila pada masa lalu peribahasa Banjar menjadi buah bibir untuk memberi nasihat kepada orang lain dalam berbagai waktu dan suasana, sekarang peribahasa Banjar hanya muncul pada saat pertunjukan kesenian lamut, madihin, dan atau pada upacara baantaran pangantin 'upacara pernikahan'. Sangat disayangkan pula, kesenian lamut, madihin, upacara baantaran pangantin, yang juga notabene adalah peninggalan masyarakat tradisional, hari demi hari, tahun demi tahun, juga semakin terlupakan.

Peribahasa Banjar didominasi oleh penampilan sosok, tabiat, dan perilaku negatif. Peribahasa ini sangat digemari dan sering muncul sebagai sarana pengajaran moral. Masyarakat Banjar sudah sangat paham bahwa penampilan sosok berprilaku negatif bukan untuk dijadikan contoh tetapi untuk dikenali sehingga prilaku negatif itu harus dijauhi. 


\section{Daftar Pustaka}

Dharmojo. 2005. Sistem Simbol dalam Munaba Waropen Papua. Jakarta: Pusat Bahasa, Departemen Pendidikan Nasional.Djoko Damono, Sapardi dkk. 2010. Simbolisme dan Imajisme dalam Sastra Indonesia. Jakarta: Pusat Bahasa, Kementerian Pendidikan Nasional.

Escarpit, Robert. 2005. Sosiologi Sastra (terjemahan Ida Sudari Husen). Jakarta: Yayasan Obor Indonesia.

Jumadi. 2013. "Mengintensifkan Peran Pendidikan Sastra untuk Membangun Karakter Siswa. Proceedings Seminar Internasional: Literature and Nation Character Building (hlm. 33-46. Banjarmasin: Fakultas Keguruan dan Ilmu Pendidikan, Unlam.

Kesuma, Dharma; Triatna, Cepi; \& Permana, Johar, H. 2011. Pendidikan Karakter Kajian Teori dan Praktik di Sekolah. Bandung: PT Remaja Rosdakarya.

Kridalaksana, Harimurti. 1993. Kamus Linguistik. Jakarta. PT Gramedia Pustaka Utama.

Kurniawan, Heru. 2012. Teori, Metode, dan Aplikasi Sosiologi Sastra. Yogyakarta: Graha Ilmu.

Lickona, T. 1991. Educating for Character, How Our Schools Can Teach Respect and Responsibility. New York: Bantam Books.

Lickona, T. Schaps, E., \& Lewis, C. 1995. Eleven principles of effective character education. Washington, DC.: Character Education Partnership.

Lickona, T. 2001. "What is effective character education?" Paper presented at The Stony Brook School Symposium on Character. www.athenaeum.edu/pdf/What is Effective Character Education.pdf

Lickona, T. 2012. Pendidikan Karakter. Terjemahan Saut Pasaribu dari Character Matters, Touchstone, New York, 2004. Bantul: Kreasi Wacana.

Lickona, T. 2013. Mendidik untuk Membentuk Karakter: Bagaimana Sekolah Dapat Pendidikan tentang Sikap Hormat dan Bertanggung Jawab. Terjemahan Juma Abdu Wamaungo dari Educating for Character: How Our School Can Teach Respect and Responsibility, 1991. Jakarta: PT Bumi Aksara.

Megawangi, Ratna. 2004. Pendidikan Karakter Solusi yang tepat untuk membangun bangsa. Jakarta: Star Energy

Nuraini Yusoff. 2013. Tun Dr. Mahathir Mohammad: Ikon pembentukan karakter bangsa. roceeding Seminar Internasional: Pengembangan peran bahasa dan sastra Indonesia mewujudkan generasi berkarakter (hlm. 11-31. Surakarta: Fakultas Keguruan dan IImu Pendidikan, Universitas Sebelas Maret.

Nuraini Yusoff. 2013. Kursus Penghayatan Karya Agung Melayu dalam Program Pensiswazahan Guru Sekolah Rendah. Proceedings Seminar Internasional: Literature and Nation Character Building (hlm. 19-31. Banjarmasin: Fakultas Keguruan dan Ilmu Pendidikan, Unlam.

Rohman, Muhammad. 2012. Kurikulum Berkarakter. Jakarta: Prestasi Pustakaraya.

Saidatul Nornis Hj. Mahali \& Mohd. Rasdi Saamah. (2013). Haiwan sebagai Perlambangan dalam Peribahasa Orang Semai. GEMA Online ${ }^{\mathrm{TM}}$ Journal of Language Studies, Volume 13(1), February 2013. 83-98.

Salimin, Saridi. 2011. Membentuk Karakter yang Cerdas. Tulungagung: Cahaya Abadi.

Zaitul Azma Zainon Hamzah \& Ahmad Fuad Mat Hassan. 2011. Bahasa dan Pemikiran dalam Peribahasa Melayu. GEMA Online Journal of Language Studies, Volume 11(3) September 2011.31-51.

Zuchdi, Damiyati; Prasetya, Zuhdan Kun; Masruri, Muhsinatun Siasah. 2013. Model Pendidikan Karakter Terintegrasi dalam Pembelajaran dan Pengembangan Kultur Sekolah. Yogyakarta: Wonosari, Mantub. 